\title{
Coastal Migration Index for Coastal Flooding Events Increased by Sea Level Rise due to Climate Change: Mexico and Cuba Case Studies
}

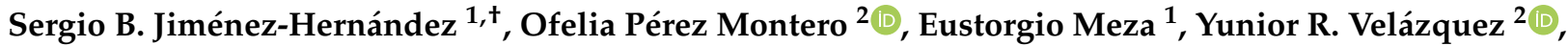 \\ Juan R. Castellanos ${ }^{2}$ (D), Esperanza Martínez-Cano ${ }^{1}$, Felipe Sosa-Pérez ${ }^{1}$ (D), Juan F. Herrera ${ }^{3}$, \\ Seweryn Zielinski ${ }^{4, *(D)}$, Benjamin Cuker ${ }^{5}$, Marcos Oliveira ${ }^{3}$, Giorgio Anfuso ${ }^{6, *(D)}$ and Celene B. Milanes ${ }^{3, *(D)}$
}

Citation: Jiménez-Hernández, S.B.; Pérez Montero, O.; Meza, E.; Velázquez, Y.R.; Castellanos, J.R.; Martínez-Cano, E.; Sosa-Pérez, F.; Herrera, J.F.; Zielinski, S.; Cuker, B.; et al. Coastal Migration Index for Coastal Flooding Events Increased by Sea Level Rise due to Climate Change: Mexico and Cuba Case Studies. Water 2021, 13, 3090. https://doi.org/10.3390/w13213090

Academic Editor: Athanasios Loukas

Received: 6 September 2021

Accepted: 29 October 2021

Published: 3 November 2021

Publisher's Note: MDPI stays neutral with regard to jurisdictional claims in published maps and institutional affiliations.

Copyright: (c) 2021 by the authors. Licensee MDPI, Basel, Switzerland. This article is an open access article distributed under the terms and conditions of the Creative Commons Attribution (CC BY) license (https:/ / creativecommons.org/licenses/by/ $4.0 /)$.
1 Center for Research and Development in Port, Maritime, and Coastal Engineering (CIDIPORT, Spanish Acronym), Centro Universitario Tampico-Madero, Tampico 89109, Tamaulipas, Mexico; sjimenez@uat.edu.mx (S.B.J.-H.); emezac@docentes.uat.edu.mx (E.M.); emartinez@docentes.uat.edu.mx (E.M.-C.); felipe.sosa@docentes.uat.edu.mx (F.S.-P.)

2 Center for Multidisciplinary Studies of Coastal Zones (CEMZOC), Universidad de Oriente, Santiago de Cuba 90400, Cuba; ofeliapm2019@gmail.com (O.P.M.); yvlabrada@gmail.com (Y.R.V.); ray910210@gmail.com (J.R.C.)

3 Program Ph.D. in Sustainable Development, Department of Civil and Environmental, Universidad de la Costa, Barranquilla 080001, Colombia; jherrera73@cuc.edu.co (J.F.H.); msilva@cuc.edu.co (M.O.)

4 Department of Hospitality and Tourism Management, Sejong University, Seoul 05006, Korea

5 Department of Marine and Environmental Science, Hampton University, Hampton, VA 23668, USA; benjamin.cuker@hamptonu.edu

6 Faculty of Marine and Environmental Sciences, University of Cádiz, 11510 Puerto Real, Spain

* Correspondence: zielinski@sejong.ac.kr (S.Z.); giorgio.anfuso@uca.es (G.A.); cmilanes1@cuc.edu.co (C.B.M.)

+ Passed away due to severe acute respiratory syndrome coronavirus 2 (SARS-CoV-2).

Abstract: This paper presents a coastal migration index (CMI) useful for decision-making in the current scenario of sea-level rise (SLR) due to climate change. The CMI includes coastal human population density, degree of urbanization, and coastal-flooding penetration. Quantitative and qualitative statistical techniques and the geographic information system ArcGIS View 9.0 were used. Further, a panel of fifteen international experts in coastal management issues was consulted to establish and validate the CMI. Results led to three index components based on 22 indicators. CMI was applied in the state of Tamaulipas, Mexico and in Santiago de Cuba province, Cuba. According to CMI estimates, the risk levels associated with SLR for human settlements analyzed in Mexico and Cuba were $5.3 \%$ and $11.0 \%$, respectively. The most severely affected communities will require resettlement. Meanwhile, the CMI determined that $15.8 \%$ of the Mexican territory studied will be able to withstand the effects of SLR through the management of engineering works that will protect human settlements. The CMI determined that $79.0 \%$, in the case of Tamaulipas, as well as $89.0 \%$ of the Cuban territory, will not require new policies or guidelines to promote conservation and protection of coastal natural resources. Lastly, the method used allowed for creation of a CMI stoplight map useful to coastal decision-makers to adopt sound management actions.

Keywords: coastal vulnerability; coastal management; coastal environmental sustainability; stoplight map; hurricanes

\section{Introduction}

Forecasts and evidence of sea level rise (SLR) in the current era of the Anthropocene engender increased vulnerability of coastal areas around the world [1-7], and this paper deals with two study areas located in Mexico and Cuba.

Mexico is located at the northern tip of Central America. The country has coasts towards the Gulf of Mexico (GoM) and the Caribbean Sea. It has important geographical 
features, among them, the Mexican Plateau, the Sierra Madre del Sur, Sierra Madre Occidental, and Sierra Madre Oriental Mountain systems. The latter is inclined towards the Gulf of Mexico between the Isthmus of Tehuantepec and the Rio Grande, including both the Frontal Sierras and the Sierras de San Carlos and Tamaulipas, with basaltic plateaus to the south. Such features influence the behavior of the meteorological variables in the Gulf of Mexico, giving rise to abundant rains and a notable occurrence of cyclones, whose trajectories are determined by pressure differences because of the heating of the northern lands during the summer and the lower temperatures of the Antillean seas and the Caribbean [8]. Along the GoM, SLR has increased, on average, $1.7 \mathrm{~mm} /$ year since 1993, with a maximum of $3 \mathrm{~mm}$ /year [9]. In coastal wetlands of the GoM, such as those associated with the Mississippi Delta, SLR increases of up to $12 \mathrm{~mm} /$ year are reported [10].

The Republic of Cuba is an insular country consisting of an archipelago of varioussized islands that contribute to an extensive coastal zone [11-15]. Coastal flooding took place in 117 different locations in Cuba, 35 of them in the southeastern region [16-18], during the 1791-2018 period due to sea level rise, the impact of energetic swell waves, cold fronts, and other extreme meteorological events, e.g., hurricanes. Therefore, SLR constitutes an immediate and growing future danger for the Cuban coast, where an increase of $6.77 \mathrm{~cm}$ of sea level was reported from 1966 to 2017 [19,20]. Future projections of SLR increase indicate scenarios of sea level rise of $29.5 \mathrm{~cm}$ for 2050 and $95.0 \mathrm{~cm}$ for $2100[19,20]$. It is projected that by 2050, Cuba will lose $2691 \mathrm{~km}^{2}$ of coastal land to permanent submergence ( $2.4 \%$ of its territory) that, in the 2100 scenario, would increase to $6370 \mathrm{~km}^{2}(5.8 \%$ of its territory). This prediction may underestimate the real losses due to insufficient data from the cays [21].

In Cuba, there are extensive coastal plains and marine terraces at different altitudes [22-24]. Submerged coastal plains predominate in the southeastern region [25]. In Santiago de Cuba, $28.6 \%$ of rural settlements occur in the coastal area and on riverine flood plains. These settlements face severe risk of flooding [19,20,26-31].

Both countries are at high risk because climate change is driving sea level rise and an increase in the intensity and magnitude of extreme meteorological phenomena (e.g., hurricanes). Both threats pose a challenge to the coastal management of the two countries. This paper addresses decision-making for the protection of coastal communities facing the challenge of SLR and a changing climate.

Tools to assess the impact of SLR increases in coastal areas include vulnerability and risk indices [32-43]. Some of these are based on territorial, urban development, and socioeconomic indicators. However, none provides land-use planning recommendations for the public to use as a tool to meet the challenge of SLR.

In this paper, we propose a methodology for determining a coastal migration index (CMI) based upon projected SLR values, the presence and typology of urban infrastructure, and population density. For this purpose, analyses and measurements were conducted to assess the following: (1) use of a statistical measure for calculating the value of structures endangered by SLR in the medium- and long-terms and (2) determination of geographic polygons for the application of CMI. Lastly, the method was validated for the coasts of Tamaulipas state in Mexico and the municipality of Guama, Cuba.

This article is written from the perspective of coastal risk management $[1,13,15,18]$. The goal is to prevent or limit damages due to coastal flooding events linked to extreme hydrometeorological phenomena such as storms and hurricanes the effects of which are enhanced by sea level rise. The proposed CMI is applicable for coastal urban, semideveloped, rural, and natural areas. The CMI is useful for regions with different physical and geographical characteristics where information and scientific data incorporating the effects of coastal forcing factors area available to determine the landward limit of flooded areas in case of energetic events. The extent (distance from shore) of coastal areas potentially affected by flooding processes in each of the two study cases was obtained from existing available information (reports, papers, etc.). Thus, the CMI often will not require additional data collection beyond what is normally available to most communities. 
As with other approaches, the CMI provides a data-based provisional assessment of the extent of coastal areas requiring management in the face of SLR. The results presented here address both regional (Mexico) and provincial (Cuba) scales, demonstrating the applicability of the CMI in different situations. While the CMI will aid in management decision-making, it also alerts authorities to the need for further, more detailed studies in particular situations facing extreme energetic events.

\section{Materials and Methods}

The development of the CMI was based on the use of statistical techniques, a geographic information system (ARCGIS View. 9.0), and consultations with expert panels. SLR was estimated with existing data. Available data allowed us to adjust the CMI to the specific conditions of each country, including hydrodynamic and high-resolution terrain-elevation models [44-46]. This research was carried out in three phases: (1) design of the CMI; (2) definition of polygons in the study area for application of the CMI; and (3) integration of results for establishing a CMI stoplight map in the test areas (see Figure 1).

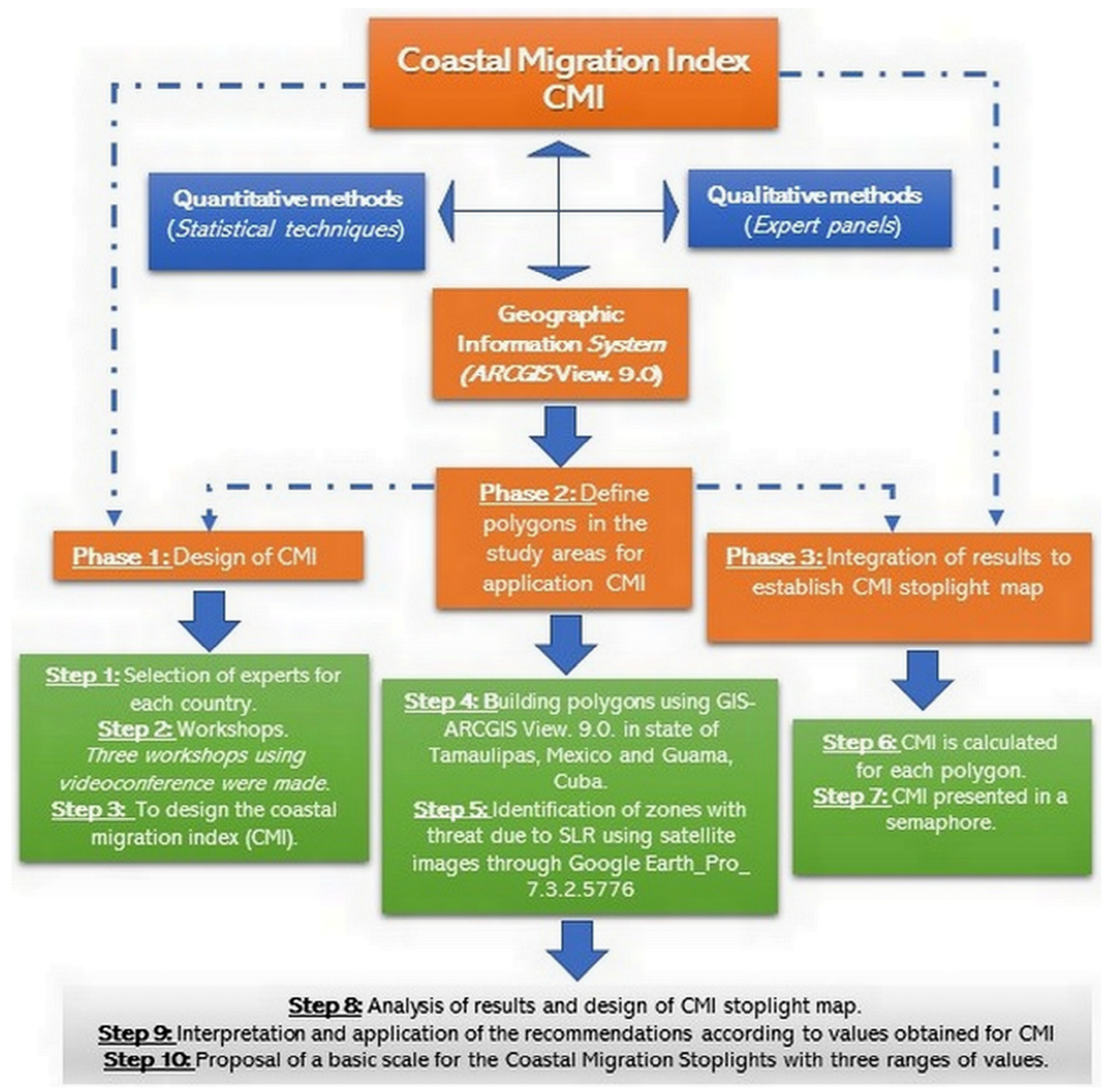

Figure 1. Methodological scheme followed in this paper. 


\subsection{Steps Followed in the Design of the Coastal Migration Index}

\subsubsection{Phase 1. Design of the CMI}

This article presents the novel concept of developing a coastal migration index (CMI) that is a statistical measure constructed from a standardized weighting of three territorial indicators: (1) coastal flooding-penetration length (distance from shore), (2) population density, and (3) degree of urbanization of the coastal area. This allows for the determination of which of the elements built in the coastal zone are likely to be affected in the short term by the penetration of the sea on land due to the intensity and frequency of extreme hydrometeorological phenomena (hurricanes). It also addresses medium- and long-term, situations taking into account the average elevation of the SLR due to climate change. This index will allow decision-makers at different levels to establish responses for mitigation (coastal engineering), adaptation (conservation of ecosystems), and human migration (actions to move the population and infrastructures to less vulnerable areas) for sustainable coastal management purposes. The CMI provides a traffic light as a graphic expression of the situations resulting from the calculation of the index in coastal areas at different scales. This aids in the communication of risk to decision-makers and the general population.

Step 1: Selecting experts.

The design of the coastal migration index resulted from discussion and consensus among specialists in coastal issues. Criteria for selecting the experts were: (a) professionals and technicians with more than ten years of experience in risk management of coastal areas, (b) extensive knowledge and information on the impact of sea level rise on both countries, (c) experts endorsed by one institution that attests to their expertise or the person being a scientific leader in the discipline. The leaders of the studies were, for the Cuban case, the Center for Multidisciplinary Studies of Coastal Zones (CEMZOC) of the Universidad de Oriente (Santiago de Cuba), and for Mexico, the Center for Research and Development in Port, Maritime, and Coastal Engineering (CIDIPORT) of the University of Tamaulipas (Tamaulipas). Fifteen experts actively participated in the workshops supporting the design and validation of the CMI.

Step 2: Workshops.

We conducted three workshops. The first addressed the question of the need for a coastal migration index. Participants considered relevant literature related to SLR and coastal-vulnerability topics [33,47-51]. A consensus of experts designed an instrument that defines the levels of intervention and adaptation necessary to face the impact of energetic events under a scenario of sea level rise, therefore useful for coastal decision-making, i.e., the protection of coastal human settlements in both countries.

The second Workshop defined the components of the coastal migration index. The experts applied the brainstorming technique and weighed three variables as the most significant to evaluate the impact of sea level rise on coastal settlements. They were: $C_{1}$ - Coastal flooding-penetration length $(\mathrm{km}) . C_{2}$-Population density at an average width of $1 \mathrm{~km} . \mathrm{C}_{3}$-Degree of urbanization of the coastal area. The data for these components were taken from the official information existing for the two countries (Cuba and Mexico) $[1,9,11,18,20,30,45]$.

Experts in the third workshop determined the weighting factors of the indicators that can interact with each component of the index. An electronic worksheet allowed experts to score the components and their indicators. Each indicator is accompanied by a weight factor, $n_{1}, n_{2}$, and $n_{3}$, respectively, which is estimated by the expert valuation of each of the 22 components listed in Table 1 . The selected indicators were activities, uses, or policies that can interact with the components and generate changes in these, according to the criteria of the experts. Components were evaluated according to the criteria developed in the workshops by the experts (Table 2).

By consensus, the experts determined the weights of each indicator in the three compartments. They considered the direct impact of the proposed indicators on the behavior of each component using the rating scale previously provided. The values 
assigned to the indicators for each component were then added, achieving the individual partial weight. The total partial weight was obtained by the sum of the three components.

Step 3: Designing the coastal migration index (CMI).

The quotient between the individual partial weights and the total partial weights was determined, obtaining the relative weight reached by each component of the index in its interaction with the 22 indicators. In this case, decimal numbers up to the value of hundredths, applying rounding up $(\geq 5)$ or down $(<5)$, were considered. The sum of the relative weights assigned to the components is equal to 1 . In correspondence with the relative weight, the weight factors $\left(n_{1}, n_{2}, n_{3}\right)$ were determined, taking for each one the respective relative weight values, up to the tenths place, applying the rounding rules.

Once the components and indicators had been evaluated, the coastal migration index was constructed, which resulted in the following mathematical expression:

$C M I=\left(\frac{\text { Coastal flooding penetration length }}{\text { Max.Pen.Len. }}\right)^{n_{1}} *\left(\frac{\text { Population Density }}{\text { Max.Pop.Dens. }}\right)^{n_{2}} *\left(\frac{\text { Urban area }}{\text { T.Area }}\right)^{n_{3}}$

Legend: Maximum penetration length (Max.Pen.Len) Maximum population density (Max.Pop.Dens).

Next, formulas to calculate three components of the coastal migration index are shown:

$$
C_{1}=\left(\frac{\text { Coastal flooding penetration length }}{\text { Max.Pen.Len. }}\right)^{n_{1}}
$$

The coastal flooding-penetration length (Equation (2)) is the landward distance (from the shoreline) reached by flooding processes and obtained by a registered historical event or from coastal flooding modeling projected using historical data. The maximum penetration length corresponds to the physical distance between the shoreline and the territory's physical, geographic limits established for the study area based upon the relief characteristics and the coastal flooding forecasts due to extreme meteorological events. In each case, existing bibliographic data were considered.

Population density is the number of people per $\mathrm{km}^{2}$ that live in the risk area of coastal flooding as previously calculated, while the maximum population density is considered as the total amount of people per $\mathrm{km}^{2}$ in a certain area (Equation (3)).

$$
C_{2}=\left(\frac{\text { Population Density }}{\text { Max.Pop.Dens. }}\right)^{n_{2}}
$$

The urban area corresponds to the geographical urban space, given in $\mathrm{km}^{2}$, that can be affected by coastal flooding, while the total area is the combined urban and non-urban space (Equation (4)).

$$
C_{3}=\left(\frac{\text { Urban area }}{\text { T.Area }}\right)^{n_{3}}
$$

The $n_{1}, n_{2}$, and $n_{3}$ parameters are the results of the weighting calculus done by the experts. The index values range between 0 and 1 when it is defined that:

$$
\begin{gathered}
\sum_{i=1}^{3} n_{i}=1 \\
C M I[0-1] . \\
C_{i}[0-1] ;
\end{gathered}
$$

Through videoconferences, the experts agreed on the results obtained and set about the task of constructing the polygons to which the index would be applied. Methodological graphics of the index design are shown in Figure 2a,b. 

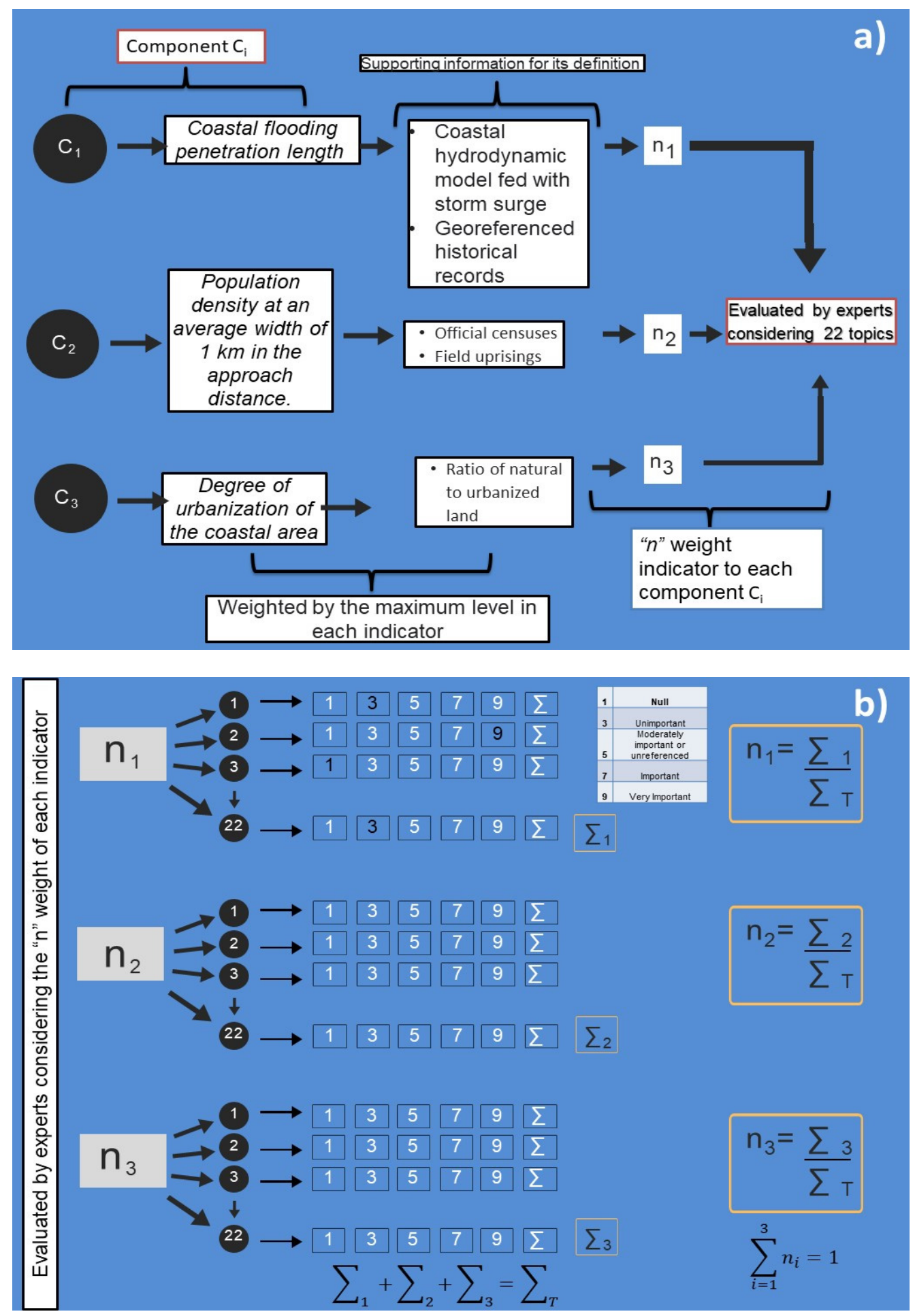

Figure 2. Methodological process for the construction of the CMI. Caption: (a) components $C_{1}-C_{2}$ and $C_{3}$ to evaluate the impact of sea level rise on coastal settlements. (b) 22 indicators were the result of the weighting calculus done by experts.

\subsubsection{Phase 2: Definition of Polygons in the Study Area for the Application of the CMI}

Steps 4 and 5: To build polygons using ARCGIS View 9.0 and identification of zones with threat due to SLR using satellite images.

With the use of satellite images and databases of the National Institute of Statistics and Geography (INEGI) of Mexico processed with software of ARCGIS View. 9.0, each polygon was characterized by determining its associated coverage or urban spot, as well as 
the population density of each. In the case of Mexico, the state of Tamaulipas was used to test the CMI proposed in this paper.

Each polygon has a constant coastal width of $10 \mathrm{~km}$ and a varied length of landward penetration delimited by land elevation according to the maximum topographic height that flooding processes could reach in the study area. To do this, the sum of the sea level rise due to effect of wind, waves, atmospheric pressure, and the historical semi-amplitude of the tide in each place is considered. This is the highest value assumed by the tide, registered in a period after the occurrence of hurricanes and other natural events, such as gales and storms. This upper limit is derived from the expectations for a category $\mathrm{V}$ hurricane on the Saffir-Simpson scale $[19,20]$. The approximate maximum altitude above mean sea level is 10 and $5 \mathrm{~m}$ for Mexico and Cuba, respectively. We also considered the geomorphological characteristics present in each coastal territory.

In the case of Cuba, the coastal area of the municipality of Guama in the province of Santiago de Cuba was considered using the current administrative political divisions. For Cuba, the information came from the studies of hazards, vulnerabilities, and risks by coastal floods $[20,23,52,53]$, as well as data published by the National Statistics and Information Office in recent years [16,17].

2.1.3. Phase 3: Integration of Results for Establishing a CMI Stoplight Map in the Test Areas

The Coastal Migration Index (CMI) is calculated for each polygon by applying the aforementioned integrated formula. The interpretation ranges for each action to be implemented are determined according to the scale of low, moderate, or high-risk scenarios. Generally, in these ranges, the numerical position that the index values occupy in different polygons is considered with respect to the lower or intermediate limits, as appropriate. In the entire class of data corresponding to the CMI by polygons, the minimum non-zero value was selected, which is assumed as the lower limit (Xmin). It was also necessary to obtain the intermediate limit (Xmed). For this, the maximum limit (Xmax), was determined as the highest value in the class of data under analysis, and the arithmetic mean of the minimum and maximum limits was calculated $[\mathrm{Xmed}=(\mathrm{X} \min +\mathrm{Xmax}) / 2]$.

Ranges for the actions to be implemented are determined according to the low, moderate, or high-risk scenarios, linking them to: REMAIN ON THE SITE (green traffic light) when the risk is low; MITIGATION (yellow traffic light) when moderation of risk requires mitigation measures (such as coastal walls, hydraulic infrastructure against floods, early warning systems, among other actions); and MIGRATE (red traffic light) in the face of high risk that would mainly force the relocation of human settlements or not allow them to expand in such conditions. The result of applying the CMI is expressed in a semaphore. As mentioned, the CMI establishes three scenarios: permanence (low risk), mitigation (moderate risk, allowing staying in a place with appropriate actions), and migration (high risk requiring relocation) (Figure 3 ).

\subsection{Study Areas}

Choosing Mexico and Cuba provided the opportunity to compare the CMI in continental and insular coastal settings. We selected the Mexican state of Tamaulipas and the Guama coastal municipality in Santiago de Cuba province, Cuba (Figure 4).

Mexico and Cuba differ in socioeconomical, physical, geographical, and population characteristics (Table 3), but both countries will experience significant impacts due to climate change induced SLR. 


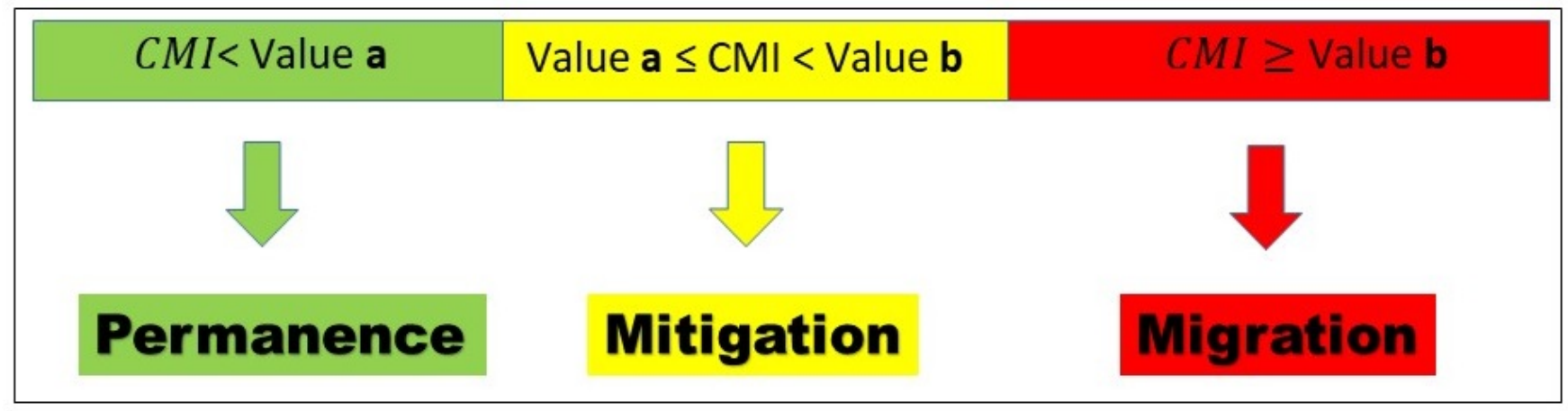

Figure 3. Stoplight value interpretation for the coastal migration index. Caption: Green: Range 1, PERMANENCE, CMI < lower limit of CMI (a value). The risk is lower for human settlements and human settlements can be maintained. Yellow: Rank 2, MITIGATION, between the lower (a value) and the intermediate (b value) limit. It is possible to mitigate the risk to human settlements with the execution of hydraulic works, i.e., to prevent extreme flooding and damage to property and infrastructure. Red: Rank 3, MIGRATION, CMI $\geq$ Intermediate limit (b value). The area has a high risk of impact from expected SLR, and human settlements will have to be relocated and existing infrastructure will have to adapt to those risk conditions. Real a and $b$ values are presented in the results section.
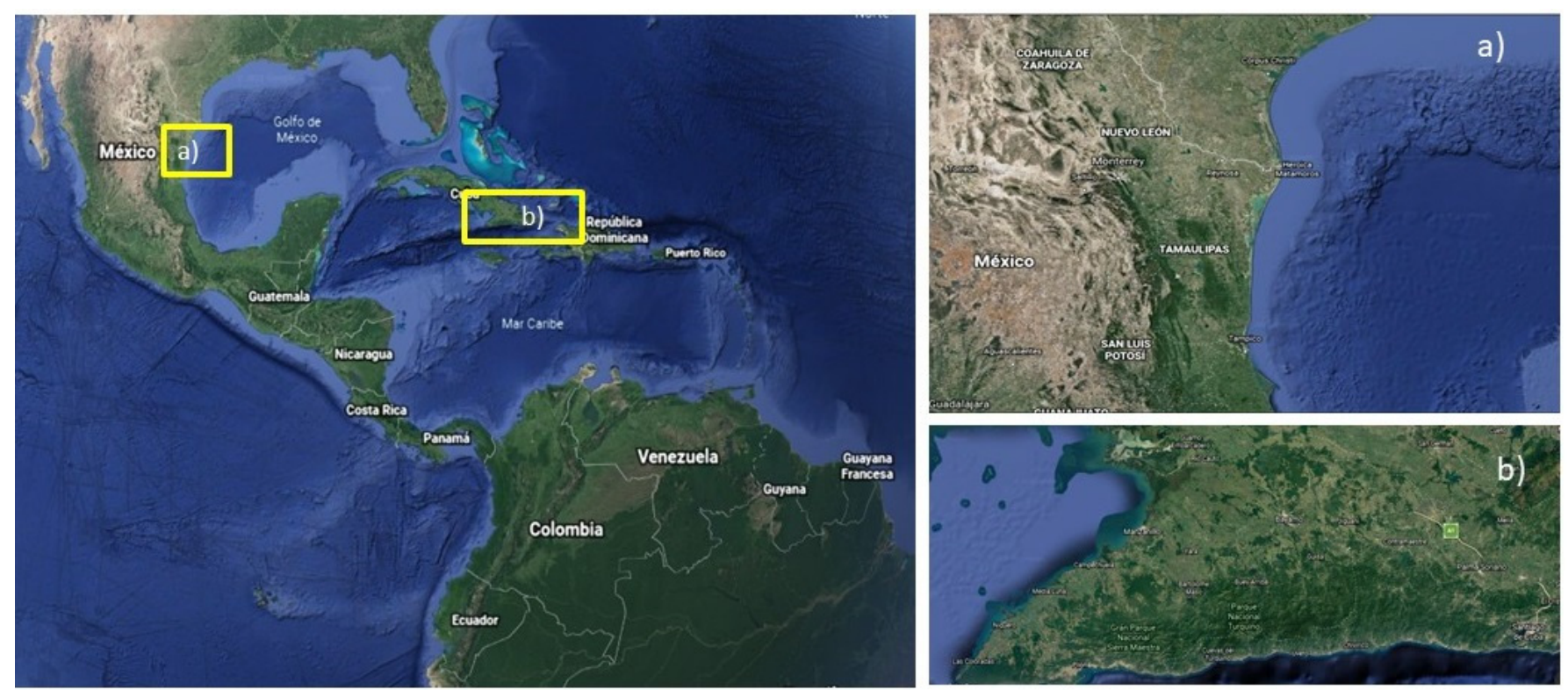

Figure 4. Study area for the application of CMI. Caption: (a) Tamaulipas State, Mexico. (b) Guama Municipality, Province of Santiago de Cuba, Cuba.

Mexico is a coastal country with more than 11 thousand kilometers of coastline, which accounts for $67 \%$ of its land, classified as marine territory. About $40 \%$ of the population and most of the bigger cities are on the coast. The coast of Mexico is between $32^{\circ} 34^{\prime} 59^{\prime}$ and $14^{\circ} 26^{\prime} 35^{\prime \prime} \mathrm{N}$ and between the $117^{\circ} 09^{\prime} 07^{\prime \prime}$ and $87^{\circ} 25^{\prime} 39^{\prime \prime} \mathrm{W}$. Tamaulipas has a population of $3,527,735$ people, of which $49.2 \%$ are men and $50.8 \%$ are women. The GoM, to the south, the central coast on the Pacific Ocean, and the land along the Caribbean Sea are heavily vulnerable to the impact of hurricanes [54]. SLR presents critical scenarios for the Mexican coasts $[9,55]$. Coastlines of Tamaulipas (one of the 17 Mexican coastal states) are on extensive coastal plains located less than $6 \mathrm{~m}$ above mean sea level, rendering many residents and properties vulnerable to the effects of storm-surge impacts [56]. 
Table 1. Component ratio of the weights, $n_{i}$, of each weight, $C_{i}$, that make up the CMI.

\begin{tabular}{|c|c|c|}
\hline Categories & Indicators & $\begin{array}{l}\text { Criteria for Weighing the Impact Factor of Each Indicator and Their Interaction with } \\
\text { the Components of CMI }\end{array}$ \\
\hline \multirow{5}{*}{ Policies } & Environmental & $\begin{array}{l}\text { To consider the impact that the existence (or absence) of environmental policies can have } \\
\text { on the implementation of the CMI for decision-makers in environmental-management } \\
\text { programs, projects, and initiatives, as well as on its implementation in urban areas with } \\
\text { different levels of population density and coastal flooding. }\end{array}$ \\
\hline & Social & $\begin{array}{l}\text { To analyze the presence of institutions, interest groups, and communities in urban areas } \\
\text { that are densely populated and vulnerable to coastal flooding }[13,24,30] \text {. }\end{array}$ \\
\hline & Economic & $\begin{array}{l}\text { To analyze the role of economic policies and the allocation of budget items to climate } \\
\text { change adaptation and mitigation measures, in particular, the rise in mean sea level and } \\
\text { the impact of extreme hydrometeorological phenomena }[9,13,24,30,47,55] \text {. }\end{array}$ \\
\hline & Sectorial & To consider all sectoral conflicts of interest existing in coastal areas. \\
\hline & Political & $\begin{array}{l}\text { To consider the role played by the existence of political will to confront climate } \\
\text { change in the execution and implementation of climate-change adaptation and } \\
\text { mitigation measures }[9,13,18] \text {. }\end{array}$ \\
\hline \multirow{2}{*}{ Uses } & Land uses & $\begin{array}{l}\text { To weigh land uses (residential, agricultural, recreational, transport, commercial, others) } \\
\text { on an urban scale in the study areas. }\end{array}$ \\
\hline & Infrastructure & $\begin{array}{l}\text { To weigh the level of urbanization, as well as the presence of heritage, built on the } \\
\text { urban scale }[13,14,30,47] \text {. }\end{array}$ \\
\hline \multirow{8}{*}{ Activities } & Tourism & $\begin{array}{l}\text { To consider the presence of tourism as an important socioeconomic and cultural activity } \\
\text { in the studied polygons, as well as the location of facilities and levels of vulnerability. }\end{array}$ \\
\hline & Fishing & $\begin{array}{l}\text { To weigh fishing as a socioeconomic and cultural activity and considering if it is sport } \\
\text { fishing or the subsistence of fishing communities. Considering the existence of fishing } \\
\text { areas, diving centers, and training areas, areas for unloading or maintenance of boats or } \\
\text { fishing gear due to the impact on decision-making in the application of the CMI. }\end{array}$ \\
\hline & Aquaculture & $\begin{array}{l}\text { To consider the role of aquaculture as a socioeconomic and cultural activity within the } \\
\text { coastal migration index. }\end{array}$ \\
\hline & Agriculture & $\begin{array}{l}\text { To weigh the role of agriculture as a socioeconomic and cultural activity of coastal } \\
\text { communities in relation to the components of the index, as well as the impact of } \\
\text { penetration of the sea on crops and the quality of life of inhabitants in the } \\
\text { coastal communities. }\end{array}$ \\
\hline & Livestock & $\begin{array}{l}\text { To analyze the existence of cattle (cows, sheep) in the study areas, as well as pastoral } \\
\text { practices in the community. }\end{array}$ \\
\hline & Energy & $\begin{array}{l}\text { To consider the role and impact of electrical or gas networks in the studied polygons } \\
\text { and their interrelation with the study components. }\end{array}$ \\
\hline & Ports & $\begin{array}{l}\text { To analyze the existence of ports in the study area and their importance for } \\
\text { the territory }[14,24] \text {. }\end{array}$ \\
\hline & Commerce & To consider the existence of free zones and maritime or land-trade flows. \\
\hline \multirow{7}{*}{$\begin{array}{l}\text { Coastal } \\
\text { Management }\end{array}$} & Conservation & $\begin{array}{l}\text { To consider stocks of protected areas, national parks, or other protected natural heritage } \\
\text { features in the coastal zone [14]. }\end{array}$ \\
\hline & Legal & $\begin{array}{l}\text { To analyze the existence of legal frameworks that support policies for confronting } \\
\text { climate change and coastal risks. }\end{array}$ \\
\hline & Governance & $\begin{array}{l}\text { To evaluate the existence of integration measures for participation of social actors in the } \\
\text { implementation, mitigation, and adaptation of actions to face climate change and } \\
\text { coastal risks. }\end{array}$ \\
\hline & Authority & $\begin{array}{l}\text { To consider the existence and implementation of coastal management policies by } \\
\text { institutions with competence in these issues. }\end{array}$ \\
\hline & Resilience & $\begin{array}{l}\text { To weigh the importance of the response and adaptation capacity for communities and } \\
\text { natural systems to face the threats associated with climate change. }\end{array}$ \\
\hline & Salt intrusion & $\begin{array}{l}\text { To analyze saline intrusion as a consequence of sea level rise on currently productive } \\
\text { areas on which coastal communities depend }[13,14] \text {. }\end{array}$ \\
\hline & Vulnerability & $\begin{array}{l}\text { To weigh different levels of vulnerabilities (structural, ecological, social, economic, } \\
\text { functional, non-structural) in the coastal area being analyzed }[18,19] \text {. }\end{array}$ \\
\hline
\end{tabular}


Table 2. Criteria for assessing the contribution of each component to each of the $C_{i}$ indicators that comprise the CMI.

\begin{tabular}{cc}
\hline No. & Scale for Assessing Criteria \\
\hline 1 & Null \\
3 & Unimportant \\
5 & Unreferenced \\
7 & Important \\
9 & Very Important \\
\hline
\end{tabular}

Table 3. Relevant comparative aspects between Mexico and Cuba.

\begin{tabular}{|c|c|c|}
\hline Aspects to Compare & Mexico & Cuba \\
\hline Land Surface $\left(\mathrm{km}^{2}\right)^{\mathrm{a}}$ & $1,964,375$ & 110,860 \\
\hline Coastline $(\mathrm{km})^{\mathrm{b}}$ & 11,000 & 5980 \\
\hline Coastline length ${ }^{\mathrm{c}}$ & $23,761 \mathrm{~km}$ & $14,519 \mathrm{~km}$ \\
\hline Gross Domestic Product (see FMI, 2016) ${ }^{d}$ & $1,063,606$ & 62,705 \\
\hline 1990 population (millions of people) & 83.94 & 10.6 \\
\hline 2010 population (millions of people) & 114.1 & 11.2 \\
\hline 2030 estimated population (millions of people) & 138 & 11 \\
\hline Ecological footprint (hectare per capita) $2007^{\mathrm{e}}$ & $2.60 \mathrm{~h}$ & $1.95 \mathrm{~h}$ \\
\hline Global Peace Index $(2017){ }^{\mathrm{f}} 163$ countries ranking. & 140 & 81 \\
\hline Human Development Index (IDH, Spanish acronym) ${ }^{g}$ & $0.767 \mathrm{~h}$ & $0.778 \mathrm{~h}$ \\
\hline
\end{tabular}

Index: ${ }^{a, b}$ National Institute of Statistics, Geography, and Informatics of Mexico. Atlas of the physical environment, 1981. https:/ / www.inegi.org.mx/app/biblioteca / ficha.html?upc=702825220525, accessed on 23 May 2021

${ }^{c}$ Coastline length, World Resources Institute. https:/ / es.wikipedia.org/wiki/Anexo:Pa\%C3\%ADses_por_longit ud_de_costa, accessed on 23 May 2021. ${ }^{\mathrm{d}}$ GDP as FMI 2016. https:/ / economipedia.com/ranking/paises-por-pib. html, accessed on 23 May 2021. ${ }^{\mathrm{e}}$ https://www.footprintnetwork.org/content/images/uploads/Ecological_Foo tprint_Atlas_2010.pdf, 2006. Living planet report 2006. https:/ / es.wikipedia.org/wiki/Huella_ecol\%C3\%B3gica, accessed on 23 May 2021. ${ }^{\mathrm{f}}$ Global Peace Index 2018, Institute for Economics and Peace (IEP). https: / / CMIo.o rg.mx/indice-paz-global-2018-via-iep/, accessed on 23 May 2021. ${ }^{g}$ Human Development Index Report, 2018 https://es.wikipedia.org/wiki/Anexo:Pa\%C3\%ADses_por_\%C3\%ADndice_de_desarrollo_humano, accessed on 23 May 2021.

Cuba's archipelago includes the island of Cuba, the Isla de la Juventud, and more than 4194 smaller islands and cays with a total area of $109,884 \mathrm{~km}^{2}[16,17]$. The archipelago of Cuba is between $19^{\circ} 49^{\prime} 36^{\prime \prime}$ and $23^{\circ} 17^{\prime} 09^{\prime \prime} \mathrm{N}$ and between the $74^{\circ} 07^{\prime} 52^{\prime \prime}$ and $84^{\circ} 57^{\prime} 10^{\prime \prime} \mathrm{W}$ meridians, which includes the Cuban Island and islands adjacent to its coasts. Cuba extends $1256 \mathrm{~km}$ from Cape San Antonio to Maisi Tip [57]. In 2019, 11,238,000 people lived in Cuba $[16,17]$. Guama coastal municipality is in the province most vulnerable to hydrometeorological events, such as hurricanes and SLR [52,53,58-61]. The Cuban study region extends to the north with the state of Gramma, and to the south with the Caribbean Sea [62]. It is in a large and narrow belt that extends from east to west across $104 \mathrm{~km}$, with an area of $94,969 \mathrm{~km}^{2}$. Guama has a population of 34,394 people. The population is established in rural and urban settlements in a coastal mountainous relief.

\section{Results}

\subsection{Determination of Polygons for the Application of CMI in the Study Areas}

Valuation of the three components, $C_{1}, C_{2}$, and $C_{3}$, of the CMI for the Tamaulipas (Mexico) study site was determined by constructing 57 polygons (Figure $5 \mathrm{a}$ ). In the case of Guama municipality [63] in Cuba, nine polygons were obtained (Figure 5b).

\subsection{Assessing the Contribution of Each Component to Each of the $C_{i}$ Indicators That Comprise the CMI Used}

The experts determined the value of the interactions between the components of the index and the 22 indicators selected by them. The values of the coefficients $\left(n_{1}, n_{2}\right.$, and $\left.n_{3}\right)$ of the components $\left(C_{1}, C_{2}\right.$, and $\left.C_{3}\right)$ of the CMI stem from the expert workshops. These are organized in Appendices A and $\mathrm{B}$. 


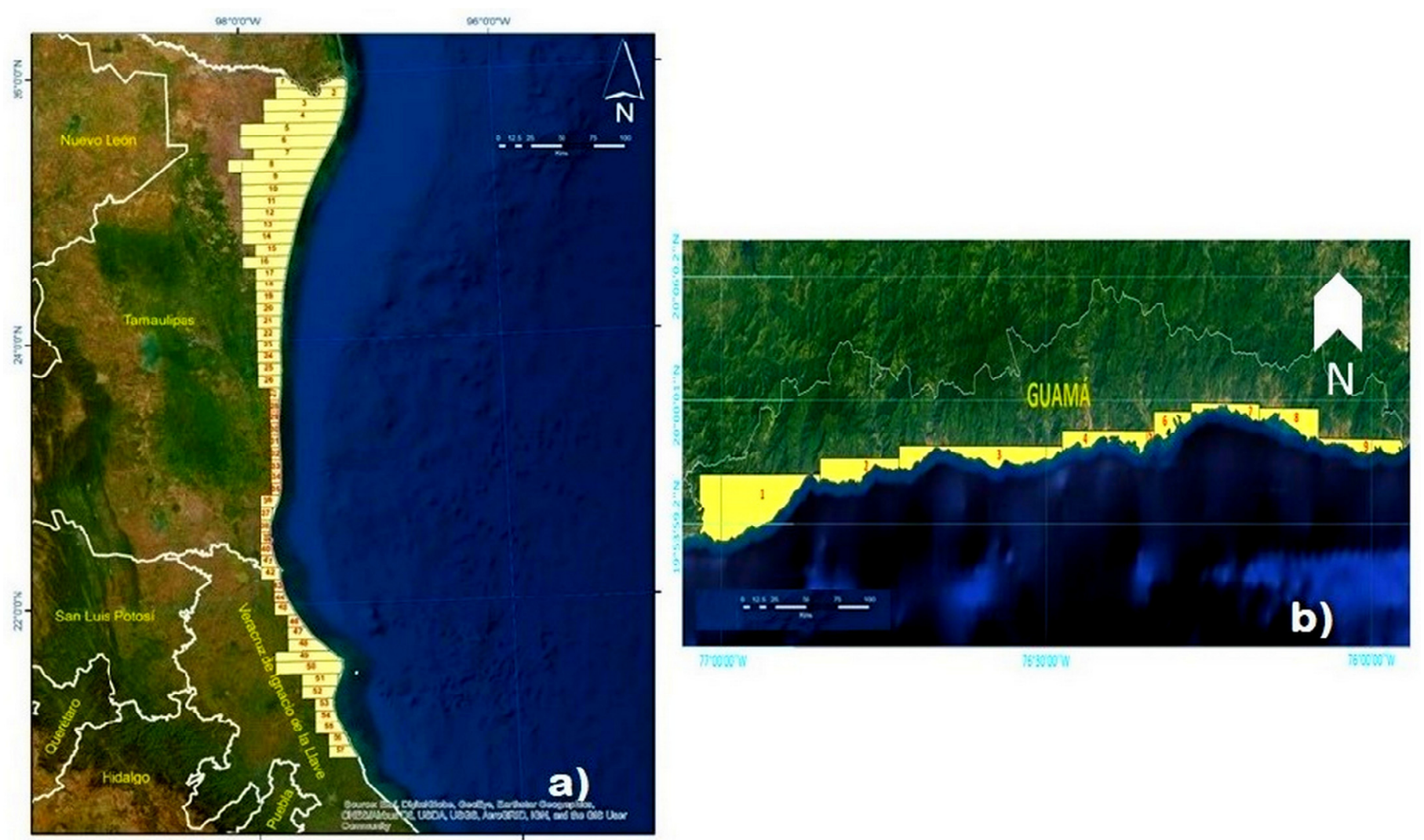

Figure 5. Identification of polygons for the application of the CMI in the study areas. Caption: (a) delimitation of the 57 polygons along the coast of Tamaulipas (Mexico) for the determination of the CMI. (b) delimitation of the 9 polygons of action along the coast of Guama, Cuba for the determination of the CMI.

\subsection{Calculation, Interpretation, and Representation for the Index That Determines the Need for Populations to Migrate to Safer Regions}

The assessed components (Appendices A and B) in (Equation (1)) were used for each one of the 57 Mexican and 9 Cuban polygons (see Figure 5a,b). Height above mean sea level established the landward boundary of each polygon, $10 \mathrm{~m}$ altitude in the case of Mexico and $5 \mathrm{~m}$ for Cuba [64]. Note that the two different boundary altitudes reflect the contrasting landforms in the study sites. We also checked all points affected by coastal floods observed in 2012 due to the effects of Hurricane Sandy (a category III storm on the Saffir-Simpson scale during impact) [18-20]. We also considered the forecasts of $28.4 \mathrm{~cm}$ and $93.1 \mathrm{~cm}$ of flooding in Chivirico, the urban municipal head of Guama (projections for the years 2050 and 2100, respectively) $[19,20]$. In Mexico, taking into account the estimated increase of $3 \mathrm{~mm} /$ year [9], by 2100, approximately $30 \mathrm{~cm}$ of sea level rise would be reached.

We included population density and degree of coastal urbanization in defining the nature of each polygon. Results obtained for the components, $C_{1}, C_{2}$, and $C_{3}$, are shown in Appendices C and D. Calculation of the population density in Guama is based on the reference values from Citma $[19,20]$. Guama includes a diverse topography, resulting in many isolated settlements.

\section{Value of Coastal Migration Index for Each Polygon of Action}

We used the results presented in Appendices $C$ and $D$ to assess the equation with the exponents determined in Appendices A and B (respectively for Mexico and Cuba). This produced the CMI values for each of the 57 polygons shown in Figure 6a. Similarly, the nine polygons processed in the case of Cuba are showed in Figure 6b. 


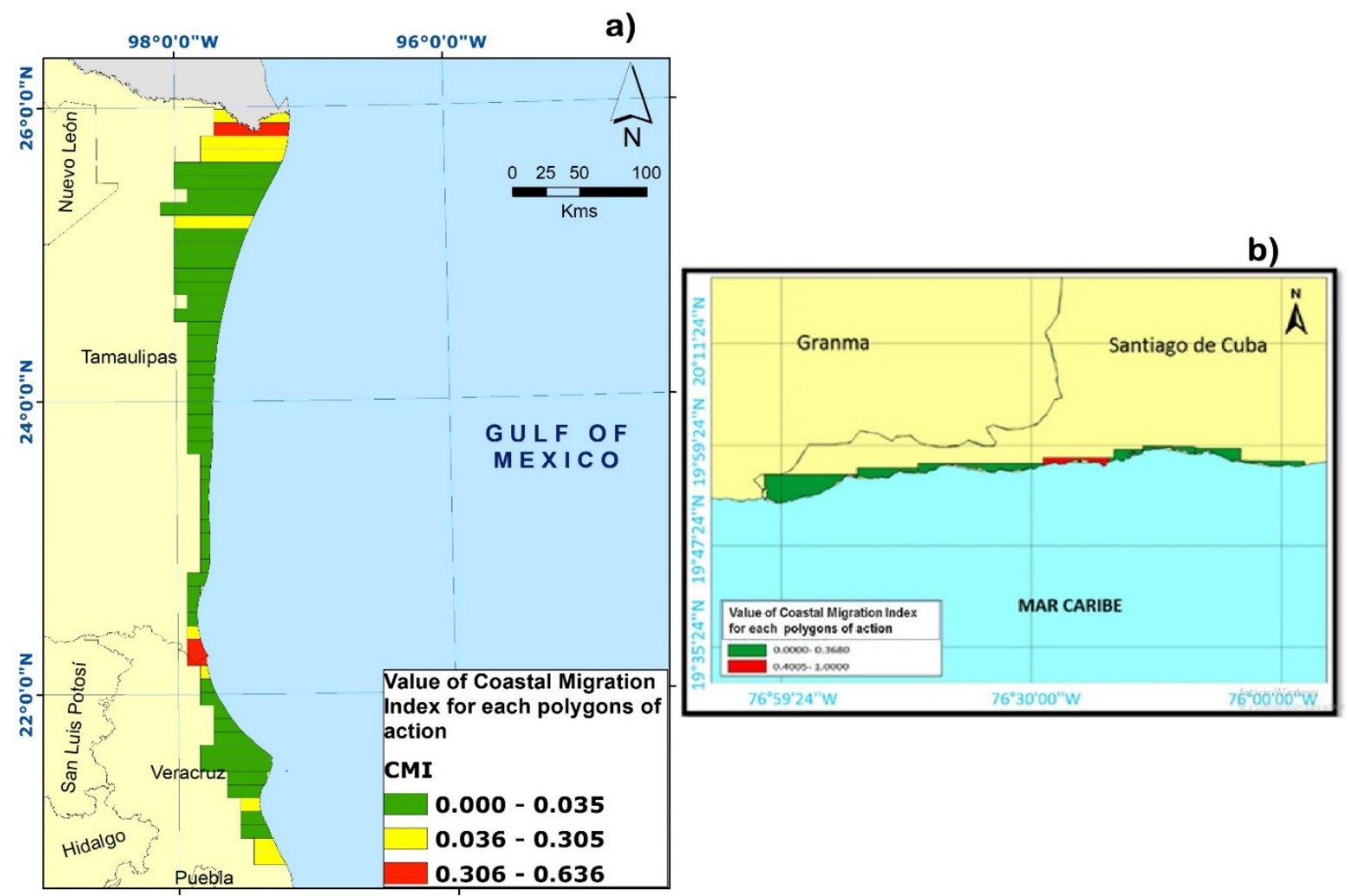

Figure 6. Graphical representation of the CMI value achieved by country. Caption: (a) representation of 57 polygons classified for Tamaulipas (Mexico) according to the ranges of interpretation in the stoplights presented in Appendix C. (b) 9 polygons showed in Appendix D for the study case of Guama (Cuba).

The range of values shown in Figure 6a was obtained using the ArcGis Jenks function mapping tool. Its use made it possible to determine the natural groupings inherent in the values obtained from the CMI (Appendix C) and to organize them into three classes linked to their recommendations for action. This classification was as follows: REMAIN for CMI values less than 0.035; MITIGATION for CMI values greater than or equal to 0.035 and less than 0.305; and MIGRATION for CMI values greater than or equal to 0.305 (Figure 7a).

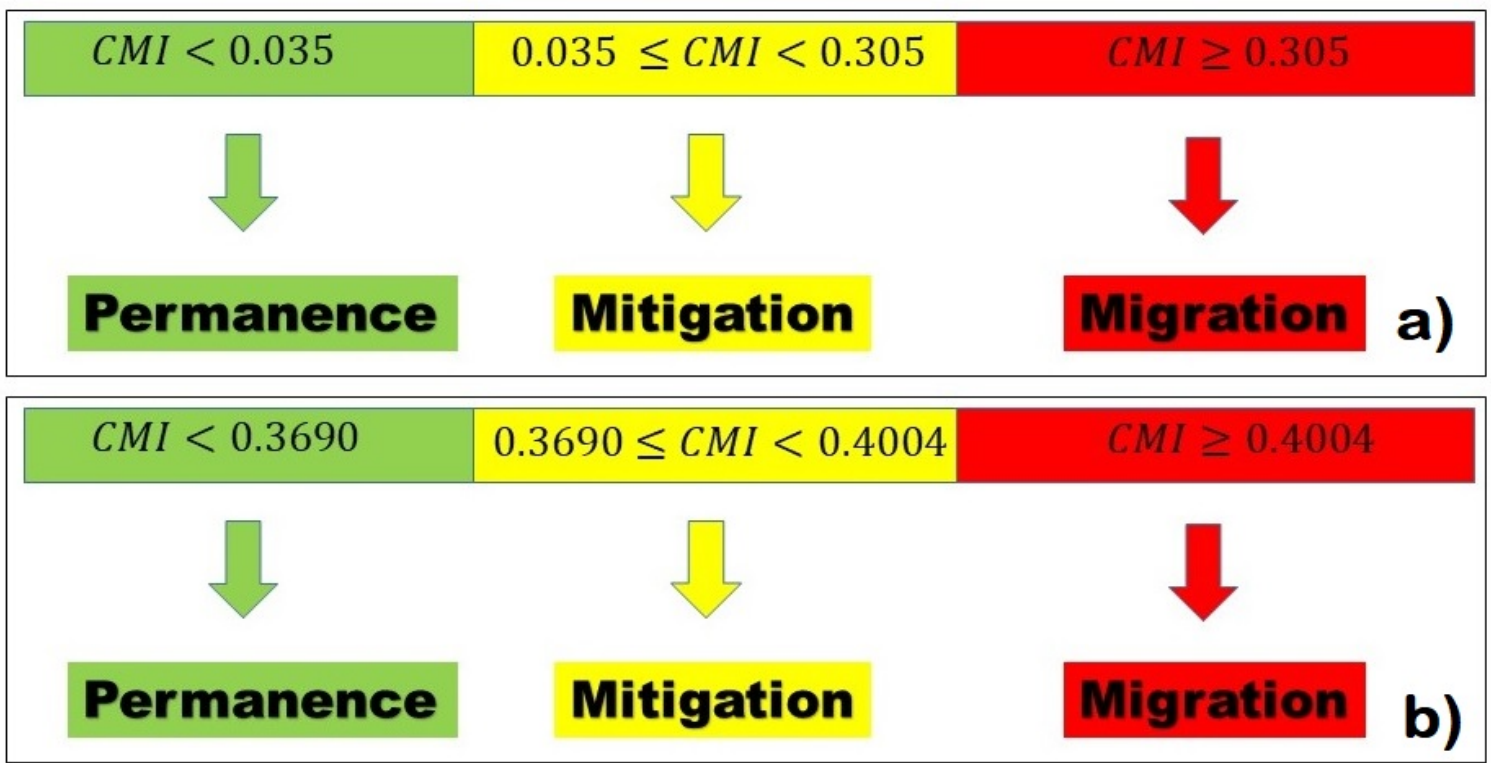

Figure 7. Interpretation ranges for CMI values associated with a stoplight. Caption: (a) Mexico case and (b) Cuba case. 
In the case of Mexico, the numerical ranges of the stoplight associated with the CMI values presented in Appendix C (ranging from 0 to 0.636) and the Jenks function of ArcGis were used, which helped to determine the natural grouping inherent in the values obtained from the CMI, allowing them to be classified into three classes linked to their action recommendations, which were: REMAIN for CMI values less than 0.035; MITIGATION for CMI values greater than or equal to 0.035 and less than 0.305 ; and MIGRATION for MIC values greater than or equal to 0.305 .

For the case of Cuba, the numerical ranges of the traffic light associated with the CMI values are presented in Appendix D (which vary between 0 and 0.49). The recommendations for action were: REMAIN for CMI values less than 0.0369; MITIGATION for CMI values greater than or equal to 0.0369 and less than 0.4004; and MIGRATION for CMI values greater than or equal to 0.4004 (Figure $7 \mathrm{~b}$ ).

Using the values shown in Appendix $C$ and Figure 6a, we organized the results by range. The application of the CMI for the site in Mexico scored $79.0 \%$ of polygons as permanence, $15.8 \%$ needing mitigation, and $5.3 \%$ requiring migration. For Cuba, $89.0 \%$ of the polygons scored in the permanence range, with $11.1 \%$ requiring migration (Appendix D and Figure 6b, respectively). Unlike the situation in Mexico, Cuba presents no polygons requiring mitigation strategies.

\section{Discussion}

Coastal vulnerability indices developed by different authors have been based on specific territorial characteristics and are dynamic due to changing rates of sea level rise (SLR) $[34,39,43,46,50,65-69]$. However, many of them depend on local information availability and require annual updates, rendering them difficult to apply in coastal environments [70]. Considering that the current scenario of SLR is increasing faster than previous predictions, it has become necessary to build versatile indices applicable on a more general basis [71].

The CMI proposed in this paper incorporates coastal physical characteristics, the degree of urbanization, and population dynamics for appropriate physical divisions of the landscape [72]. The CMI also accounts for marine dynamics, such as coastal floodingpenetration length. The component is directly associated with the beach slope that is easily applied to distinct places in time and space. Even though authors such as Dou et al. [72] include the beach slope to evaluate their coastal-risk index, the consideration of multiple parameters in CMI evaluation makes it very specific for spatial applications in all types of coastal ecosystems.

Some authors state that not all indices are applicable in all contexts [69]. Some indices used to assess coastal vulnerability in an SLR context are presented at a national scale of application $[43,73]$. However, most authors validate vulnerability indices at the regional scale [74-81]. The coastal migration index (CMI) was developed to be applied on a regional and local scale. Our proposal lines up with the index designed by McLaughlin and Cooper [39] and the CMI uses commonly available data for the assessment of these three components (1) coastal flooding-penetration length $(\mathrm{km})$; (2) population density at an average width of $1 \mathrm{~km}$; and (3) degree of urbanization of the coastal area. Our proposal is in correspondence with the methodological proposal of Özyurt and Ergin [77]. The authors focus on identifying those regions where the various effects of sea-level rise may be the greatest.

Other indices also include population density, urbanization, and measures of vulnerability $[82,83]$. However, they use the rise in mean sea level with little account for extreme events. The CMI offers most coastal countries and insular nations an effective tool to address SLR [84]. Further, our CMI proposal was validated in two different countries with good results. In both cases, the CMI provided decision-makers with a novel and comprehensive tool for making choices about adaptation actions in the face of rising sea levels. 
Various coastal-vulnerability indices provide information on possible changes in the coastline [85,86]. Some metrics include a hazard subindex [87], a sensitivity indicator [88], and a susceptibility index [82]. The research of Rizzo et al. [89] integrated into one index the analysis of seven subindices that include beach morphology, dune morphology, shoreline evolution, coastal runup, the fluvial system, storm surge, and topography [89]. Bautista and Bautista-Hernández [90] designed a set of routines for calculating derived variables most used in land evaluation, including agroclimatic indices, probability of rainfall by month, and others [90].

The CMI does not analyze changes in coastal dynamics and forcing agents. Once the impacts of flooding on the built and natural heritage of coastal areas have been determined, the index offers a tool to decide what action should be taken by coastal managers. The CMI complements other coastal management tools. To be clear, the CMI does not address the dynamic drivers of coastal environments, nor does it predict the future. Instead, it informs the decision-making process by synthesizing what is already documented about the coastal system at hand.

The CMI expands this approach with the inclusion of the range of values required to inform appropriate decisions by policy makers. This novel aspect is missing from other studies.

The CMI has three basic components: characterization of a coastal area in geomorphological, urban, and demographic terms. This simplicity allows for rapid quantification of the CMI. The basic information for evaluating the CMI is generally available in most of the world's coastal areas [91]. The versatility of the use and application of the CMI is demonstrated for the evaluation of coastal risks with basic and easy-to-determine information.

The CMI offers the opportunity to manage risks in the face of hydrometeorological threats (Figure 3). This not only applies to human settlements and the built environment but also allows for consideration of adaptation and/or mitigation alternatives to preserve the integrity of ecosystems [92].

The CMI allows the inclusion of important ecological information. For example, the dialectical relationship between biotic potential and environmental resistance to population growth for different populations of organisms can be included. Such aspects were incorporated during the analysis of the interactions between the 22 indicators and the components of the index (Appendices A and B). The CMI addresses ecological security and ecosystem services by including consideration of biogeochemical cycles, climate regulation and soil formation. Ecosystem services, such as protection against natural phenomena, prevention of coastal flooding, and agricultural and recreational uses of the land depend on these functions.

The analysis of the aforementioned indicators (Table 1) also corresponds to the ecosystem functions of production (environmental measures, energy, and agriculture) of information (social, economic, sectoral, political, risk, tourism, ports, trade, legal, governance, governability), habitats (infrastructure, fishing, aquaculture, livestock) and protection (saline intrusion, resilience).

One of the challenges for the CMI was its validation, which was done on two levels. The first of these was the consultation with local experts to determine the weight factor of each of the three components of the CMI, where the experience of the participants was fundamental in the evaluation of the 22 factors involved. Although the evaluation process has a quantitative representation, it is not without subjectivity. But it is a requirement that the participants in the evaluation have proven experience in coastal management in some of its variants: urban, environmental, and/or risk [93].

The 22 indicators resulting from this research have different scopes. These correspond to the implementation of policies and land uses on the urban scale (states, municipalities, cities). Others correspond to uses, activities, and characteristics of coastal management considering socioeconomic and cultural aspects of the communities that need protection or permanent migration actions. All the indicators determine the behavior of the CMI. 
The CMI is very flexible to adapt or adjust the indicators according to different realities and contexts.

The second level of validation of the CMI was its application in two coastal regions with very different geomorphological, urban, and sociodemographic characteristics, such as the coasts of the state of Tamaulipas in Mexico (sandy coast with a gentle slope, population centers, and large urban areas) and the coasts of the municipality of Guama in Cuba (rocky coast with steep slopes and lower population density and less urban coverage). An example of this type of risk-analysis approach is also presented by Pricope et al. [94] and Jaranovic et al. [95]. These works mandate information that is more difficult to achieve, requiring extensive information on erosion and the return periods of hydrometeorological phenomena, such as hurricanes and gales.

With these comparative results, it was possible to demonstrate the adaptability of the CMI to assess coastal risks with basic information, and quickly $[13,29,96,97]$, contrary to other indices that require very specific information from each site, which is expensive to obtain $[49,98-106]$. We agree with authors $[107,108]$ who have explained the importance of choosing and implementing specific actions in each polygon according to the communities' needs and vulnerabilities.

In the case of Mexico, the CMI assessment produced a low percentage of coastal areas in red zones that require relocation (5.26\%). The highly concentrated populations, gradual slopes, and fragile infrastructure of the red zones are consistent with their CMI scores. The CMI values provide a technical way to quantify risk and to establish and support policies that promote the relocation of high-risk human settlements or to no longer allow their expansion under such conditions.

Bartlett \& Smith [108] and Seenath et al. [109] mentioned the importance of geographic information systems (GIS) for coastal zone management and coastal flooding-vulnerability assessment. In the second article, the authors presented two types of tools that are commonly employed for SLR analysis. The first one is based on hydrodynamic models, and the second one on GIS tools [109]. The CMI takes into account a GIS coastal digital elevation model, as well as storm surge and SLR due to the effect of wind, waves, atmospheric pressure, and the historical semi-amplitude of the tide for the Cuban [11-14,18-20,23] and the Mexican cases [9,55]. In both situations, we used data on bathymetry and elevation for scenarios of SLR, as done by others for Trinidad and Tobago [109].

We demonstrated the applicability of the CMI at regional and provincial scales. This facilitates evaluation across the urbanization spectrum from low to high population densities. Additionally, the use of the traffic-light method contributes to raising the knowledge of the population when it is used within environmental education programs.

The strength of the CMI lies in the consultation of experts for the weighting of its components. The aforementioned validates the locally achieved results as a support in the establishment of public policies and the promotion of sustainable coastal development. Additionally, the CMI allows strengthening actions to mitigate risk in areas of less vulnerability and increase their resilience in the face of increasing intensities and duration of storm surges due to global climate change.

\section{Conclusions}

The CMI offers a statistical measure built on a few elements to evaluate the risks of damage in coastal zones due to extreme events such as hurricanes in a time of SLR and climate change. This index will enable decision-makers at different levels to establish mitigation (coastal engineering infrastructure), as well as adaptive (ecosystem conservation) and migration responses (displacement of populations and infrastructure to less vulnerable areas) for greater protection.

The CMI provides an affordable and easily adaptable approach for making informed decisions regarding the growing threat of SLR. It combines objective criteria (population density, degree of urbanization, elevation, historic flooding data) with the wisdom of experts familiar with local conditions. 
The expert advice ranks the various parameters or indicators in the context of the local conditions. The application of the CMI to portions of coastal Mexico and Cuba demonstrates its validity for suggesting appropriate actions to protect communities in the face of SLR. Policymakers and managers can use the CMI to determine if the community is safe to remain in place (permanence), requires actions to prepare the community to stay put (mitigation), or must move to a new and safer area (migration).

Author Contributions: S.B.J.-H.: formulation of the general idea of the work and its coordination; coastal migration index proposal and methodological development. E.M.-C. and E.M.: review and validation of the methodology for determining the coastal migration index in Mexico; S.B.J.-H., E.M.-C. and E.M.: organization, development, and analysis of information from expert consultation workshops and contribution of workshop conclusions; F.S.-P.: implementation of the geographic information system of the project and spatial analysis to determine the coastal migration index and elaboration of thematic maps; O.P.M., C.B.M., Y.R.V., J.R.C. and J.F.H.: coordination of the validation of the CMI in Cuba, article writing, and methodological review; G.A., Y.R.V., C.B.M., M.O. and J.F.H.: analysis of data and validation of the proposal; J.R.C., B.C., S.Z., M.O. and J.F.H.: analysis of satellite images; C.B.M., O.P.M., S.Z., G.A. and B.C.: writing and reviewing the style of the article. All authors have read and agreed to the published version of the manuscript.

Funding: Partial financial support for this research was provided to OGFPI trough Project PS223LH001016, named "Monitoring and integrated management of coastal ecosystems in the face of climate change in the eastern region of Cuba (ECOS)" coordinated by Universidad de Oriente in Santiago de Cuba. Other funding was provided to one of the corresponding authors by the Columbian project in Barranquilla [grant numbers INV.1106-01-002-15], named "Cultural practices and environmental certification of beaches: a contribution for the sustainable development in the insular states".

Institutional Review Board Statement: Not applicable.

Informed Consent Statement: Not applicable. The study did not involve humans or animals.

Data Availability Statement: Data are confidential.

Acknowledgments: This research was developed under an international collaboration relationship between the Center for Research and Development in Port, Maritime, and Coastal Engineering (CIDIPORT), Universidad Autonoma de Tamaulipas, Mexico, the Center for Multidisciplinary Studies of Coastal Zones (CEMZOC) of Universidad de Oriente in Cuba, and Universidad de la Costa in Colombia. We appreciate the support received from PROMEP's 2019 UAT Institutional Support to conduct research stays during this project. The authors want to express their gratitude to the members of the PROPLAYAS Network, as well as members of the Cathedra "Stephen Olsen", of which some are part. This work is a contribution to the PAI Research Group RNM-328 (Junta de Andalucía, Spain).

Conflicts of Interest: The authors declare that they have no known competing financial interests or personal relationships that could have appeared to influence the work reported in this paper.

\section{Appendix A}

Table A1. Assessment of coefficients $n_{1}, n_{2}$ and $n_{3}$ of the $C_{i}$ components of the CMI in Case A: Tamaulipas, Mexico.

\begin{tabular}{|c|c|c|c|c|c|c|c|c|c|c|c|c|c|c|c|c|c|c|c|c|c|}
\hline \multirow{3}{*}{ Component } & \multicolumn{20}{|c|}{ Assessment of Weight Factors of Coastal Migration Index Components } & \multirow{3}{*}{ Relative Weight } \\
\hline & \multicolumn{19}{|c|}{ Indicators (I) } & \multirow[t]{2}{*}{ Partial Weight } & \\
\hline & 1 & 2 & 3 & 4 & 5 & 6 & 7 & 89 & 910 & 011 & 121 & 131 & 1415 & 16 & 171 & 181 & 1920 & 021 & 22 & & \\
\hline$C_{1}$ & 3 & 7 & 7 & 1 & 9 & 5 & 1 & 93 & 33 & 1 & 99 & 99 & 5 & 9 & 73 & $\begin{array}{ll}3 & 1\end{array}$ & $\begin{array}{ll}1 & 1\end{array}$ & 1 & 1 & 104 & 0.31 \\
\hline$C_{2}$ & 7 & 7 & 7 & 9 & 7 & 5 & 5 & $\begin{array}{ll}9 & 9\end{array}$ & $\begin{array}{ll}9 & 7\end{array}$ & 5 & $\begin{array}{ll}3 & 1\end{array}$ & $\begin{array}{ll}1 & 1\end{array}$ & 5 & 1 & 73 & 33 & $\begin{array}{ll}3 & 7\end{array}$ & 5 & 9 & 122 & 0.36 \\
\hline \multirow[t]{2}{*}{$C_{3}$} & 9 & 9 & 5 & 7 & 9 & 3 & 5 & $\begin{array}{ll}9 & 7 \\
\end{array}$ & $\begin{array}{ll}7 & 7 \\
\end{array}$ & 5 & $\begin{array}{ll}3 & 1 \\
\end{array}$ & $\begin{array}{ll}1 & 1 \\
\end{array}$ & 7 & 1 & $\begin{array}{ll}3 & 1 \\
\end{array}$ & 19 & $\begin{array}{ll}9 & 7 \\
\end{array}$ & 1 & 5 & 114 & 0.34 \\
\hline & & & & & & & & & & & & & & & & & & & & 340 & 1 \\
\hline
\end{tabular}

Caption: Indicators (I) 1. Land uses, 2. Infrastructure, 3. Environmental, 4. Social, 5. Economic, 6. Sectorial, 7. Political, 8. Salt intrusion, 9. Vulnerability, 10. Tourism, 11. Fishing, 12. Aquaculture, 13. Agriculture, 14. Livestock, 15. Energy, 16. Ports, 17. Commerce, 18. Conservation, 19. Legal, 20. Governance, 21. Authority, 22. Resilience. Components (C) $C_{1}$ Coastal flooding-penetration length, $C_{2}$ Population density, $C_{3}$ Degree of urbanization of the coastal zone. 


\section{Appendix B}

Table A2. Assessment of coefficients $n_{1}, n_{2}$ and $n_{3}$ of the $C_{i}$ components of CMI (Case B: Guama case, Santiago de Cuba, Cuba. See caption of Table A1. explanation of coefficients.

Assessment of Weight Factors of Coastal Migration Index Components

\begin{tabular}{|c|c|c|c|c|c|c|c|c|c|c|c|c|c|c|c|c|c|c|c|c|c|c|c|c|}
\hline \multirow{2}{*}{ Component } & \multicolumn{22}{|c|}{ Indicators } & \multirow{2}{*}{ Partial Weight } & \multirow{2}{*}{ Relative Weigh } \\
\hline & 1 & 2 & 3 & 4 & 5 & 6 & 7 & 8 & 9 & 10 & 11 & 12 & 13 & 14 & 15 & 16 & 17 & 18 & 19 & 20 & 21 & $\overline{22}$ & & \\
\hline$C_{1}$ & 5 & 7 & 9 & 7 & 3 & 5 & 1 & 7 & 7 & 3 & 1 & 1 & 7 & 1 & 1 & 3 & 1 & 5 & 1 & 1 & 1 & 1 & 78 & 0.24 \\
\hline$C_{2}$ & 7 & 7 & 5 & 9 & 7 & 5 & 9 & 5 & 9 & 7 & 5 & 1 & 3 & 3 & 3 & 1 & 5 & 5 & 7 & 7 & 7 & 9 & 126 & 0.39 \\
\hline \multirow[t]{2}{*}{$C_{3}$} & 9 & 9 & 7 & 5 & 9 & 5 & 9 & 5 & 7 & 5 & 3 & 1 & 3 & 3 & 5 & 1 & 5 & 1 & 7 & 7 & 7 & 5 & 118 & 0.37 \\
\hline & & & & & & & & & & & & & & & & & & & & & & & 322 & 1 \\
\hline
\end{tabular}

\section{Appendix C}

Table A3. Evaluation of components of (Equation (1)) that required determination for each of the 57 actuation polygons by defining the value of CMI for $n_{1} \times 0.3 ; n_{2} \times 0.4 ; \mathrm{y}, n_{3} \times 0.3$, in the case of Mexico.

\begin{tabular}{|c|c|c|c|c|}
\hline Polygon & $C_{1}$ & $C_{2}$ & $C_{3}$ & CMI \\
\hline 1 & 0.70513 & 0.00852 & 0.04946 & 0.054 \\
\hline 2 & 0.70513 & 0.84059 & 0.39648 & 0.636 \\
\hline 3 & 0.83333 & 0.01323 & 0.04595 & 0.067 \\
\hline 4 & 0.79487 & 0.00391 & 0.02962 & 0.035 \\
\hline 5 & 1.00000 & 0.00528 & 0.00672 & 0.027 \\
\hline 6 & 0.93590 & 0.00458 & 0.00541 & 0.024 \\
\hline 7 & 0.74359 & 0.00196 & 0.00625 & 0.016 \\
\hline 8 & 0.93590 & 0.00274 & 0.00820 & 0.022 \\
\hline 9 & 0.74359 & 0.01344 & 0.01626 & 0.047 \\
\hline 10 & 0.69231 & 0.00185 & 0.00532 & 0.015 \\
\hline 11 & 0.64103 & 0.00355 & 0.00449 & 0.018 \\
\hline 12 & 0.60256 & 0.00029 & 0.00036 & 0.003 \\
\hline 13 & 0.56410 & 0.00017 & 0.00075 & 0.003 \\
\hline 14 & 0.52564 & 0.00083 & 0.00230 & 0.008 \\
\hline 15 & 0.37180 & 0.00010 & 0.00316 & 0.003 \\
\hline 16 & 0.46154 & 0.00654 & 0.00802 & 0.025 \\
\hline 17 & 0.30769 & 0.00299 & 0.00836 & 0.016 \\
\hline 18 & 0.29487 & 0.00014 & 0.00175 & 0.003 \\
\hline 19 & 0.28205 & 0.00004 & 0.00000 & 0.000 \\
\hline 20 & 0.26923 & 0.00112 & 0.00582 & 0.010 \\
\hline 21 & 0.25641 & 0.00062 & 0.00286 & 0.006 \\
\hline 22 & 0.25641 & 0.00032 & 0.00043 & 0.003 \\
\hline
\end{tabular}


Table A3. Cont.

\begin{tabular}{|c|c|c|c|c|}
\hline Polygon & $C_{1}$ & $C_{2}$ & $C_{3}$ & CMI \\
\hline 23 & 0.24359 & 0.00039 & 0.00181 & 0.004 \\
\hline 24 & 0.24359 & 0.00011 & 0.00000 & 0.000 \\
\hline 25 & 0.24359 & 0.00574 & 0.02474 & 0.027 \\
\hline 26 & 0.24359 & 0.00016 & 0.00000 & 0.000 \\
\hline 27 & 0.10256 & 0.00013 & 0.00000 & 0.000 \\
\hline 28 & 0.08974 & 0.00022 & 0.00165 & 0.002 \\
\hline 29 & 0.08974 & 0.00004 & 0.00000 & 0.000 \\
\hline 30 & 0.07692 & 0.00047 & 0.00564 & 0.005 \\
\hline 31 & 0.07692 & 0.00080 & 0.01233 & 0.007 \\
\hline 32 & 0.08974 & 0.00011 & 0.00000 & 0.000 \\
\hline 33 & 0.08974 & 0.00201 & 0.01434 & 0.011 \\
\hline 34 & 0.08974 & 0.00115 & 0.01883 & 0.010 \\
\hline 35 & 0.08974 & 0.00001 & 0.00000 & 0.000 \\
\hline 36 & 0.17949 & 0.00025 & 0.00000 & 0.000 \\
\hline 37 & 0.12821 & 0.00164 & 0.01123 & 0.011 \\
\hline 38 & 0.10256 & 0.00177 & 0.00916 & 0.010 \\
\hline 39 & 0.10256 & 0.00265 & 0.21203 & 0.030 \\
\hline 40 & 0.11539 & 0.00817 & 0.52373 & 0.063 \\
\hline 41 & 0.15385 & 0.21760 & 0.95849 & 0.306 \\
\hline 42 & 0.19231 & 1.00000 & 1.00000 & 0.610 \\
\hline 43 & 0.07692 & 0.02405 & 0.15293 & 0.059 \\
\hline 44 & 0.11539 & 0.00388 & 0.01736 & 0.017 \\
\hline 45 & 0.17949 & 0.00588 & 0.03057 & 0.027 \\
\hline 46 & 0.12821 & 0.00077 & 0.00320 & 0.005 \\
\hline 47 & 0.21795 & 0.00293 & 0.00675 & 0.014 \\
\hline 48 & 0.34615 & 0.00310 & 0.00592 & 0.015 \\
\hline 49 & 0.62821 & 0.00958 & 0.00642 & 0.030 \\
\hline 50 & 0.67949 & 0.00921 & 0.00855 & 0.033 \\
\hline 51 & 0.37180 & 0.01060 & 0.01265 & 0.032 \\
\hline 52 & 0.32051 & 0.01083 & 0.01754 & 0.035 \\
\hline 53 & 0.17949 & 0.01814 & 0.05698 & 0.051 \\
\hline 54 & 0.21795 & 0.00466 & 0.01764 & 0.022 \\
\hline 55 & 0.28205 & 0.00633 & 0.01644 & 0.026 \\
\hline 56 & 0.20513 & 0.21251 & 0.36718 & 0.248 \\
\hline 57 & 0.26923 & 0.01243 & 0.06558 & 0.052 \\
\hline
\end{tabular}




\section{Appendix D}

Table A4. Evaluation of components of (Equation (1)) that required determination for each of the 9 actuation polygons by defining the value of CMI for $n_{1} \times 0.2 ; n_{2} \times 0.4 ; \mathrm{y}, n_{3} \times 0.4$, in case of Cuba.

\begin{tabular}{ccccc}
\hline Polygon & $\boldsymbol{C}_{\mathbf{1}}$ & $\boldsymbol{C}_{\mathbf{2}}$ & $\boldsymbol{C}_{\mathbf{3}}$ & CMI \\
\hline 1 & 1.09239 & 0.4719 & 0 & 0 \\
\hline 2 & 0.93809 & 0.39415 & 0 & 0 \\
\hline 3 & 0.76171 & 0.46029 & 0.1291 & 0.3062 \\
\hline 4 & 0.92909 & 1 & 0.17853 & 0.4947 \\
\hline 5 & 1 & 0.14649 & 0 & 0 \\
\hline 6 & 0.89609 & 0.32355 & 0 & 0 \\
\hline 7 & 0.78999 & 0.49393 & 0 & 0 \\
\hline 8 & 0.93898 & 0.49746 & 0 & 0 \\
\hline 9 & 0.98375 & 0.60123 & 0 & 0 \\
\hline
\end{tabular}

\section{References}

1. Milanés, C.B.; Montero, O.P.; Szlafsztein, C.F.; Pimentel, M.A.D.S. Climate change and spatial justice in coastal planning in Cuba and Brazil. Ambient. Soc. 2020, 23. [CrossRef]

2. López-Dóriga, U.; Jiménez, J.A.; Valdemoro, H.I.; Nicholls, R.J. Impact of sea-level rise on the tourist-carrying capacity of Catalan beaches. Ocean Coast. Manag. 2019, 170, 40-50. [CrossRef]

3. Chen, W.; Wang, X.; Deng, S.; Liu, C.; Xie, H.; Zhu, Y. Integrated urban flood vulnerability assessment using local spatial dependence-based probabilistic approach. J. Hydrol. 2019, 575, 454-469. [CrossRef]

4. Da Silveira, Y.G.; Bonetti, J. Assessment of the physical vulnerability to erosion and flooding in a sheltered coastal sector: Florianópolis Bay, Brazil. J. Coast. Conserv. 2018, 23, 303-314. [CrossRef]

5. Chambers, D.P.; Cazenave, A.; Champollion, N.; Dieng, H.; LloveL, W.; Forsberg, R.; Von Schuckmann, K.; Wada, Y. Evaluation of the Global Mean Sea Level Budget between 1993 and 2014. Surv. Geophys. 2016, 38, 309-327. [CrossRef]

6. Benassai, G.; Di Paola, G.; Aucelli, P.P.C. Coastal risk assessment of a micro-tidal littoral plain in response to sea level rise. Ocean Coast. Manag. 2015, 104, 22-35. [CrossRef]

7. Cazenave, A.; Dieng, H.-B.; Meyssignac, B.; Von Schuckmann, K.; Decharme, B.; Berthier, E. The rate of sea-level rise. Nat. Clim. Chang. 2014, 4, 358-361. [CrossRef]

8. López de Llergo, R. Principales rasgos geográficos de la República Mexicana. Investig. Geogr. 2003, 26-41. Available online: http: / /ww w.scielo.org.mx/scielo.php?script=sci_arttext\&pid=S0188-46112003000100007\&lng=es\&tlng=es.(accessedon10April2020). [CrossRef]

9. Donoghue, J.F. Sea level history of the northern Gulf of Mexico coast and sea level rise scenarios for the near future. Clim. Chang. 2011, 107, 17-33. [CrossRef]

10. Jankowski, K.L.; Tornqvist, T.; Fernandes, A.M. Vulnerability of Louisiana's coastal wetlands to present-day rates of relative sea-level rise. Nat. Commun. 2017, 8, 14792. [CrossRef]

11. Batista, C.M.; Montero, O.P. An inquiry into land-use planning and integrated coastal zone management: The Cuban experience. Ocean Yearb. Online 2012, 26, 509-532. [CrossRef]

12. Milanés-Batista, C.; Tamayo-Yero, H.; De Oliveira, D.; Alvarez, J.R.N. Application of business intelligence in studies management of hazard, vulnerability and risk in Cuba. IOP Conf. Ser. Mater. Sci. Eng. 2020, 844, 012033. [CrossRef]

13. Batista, C.M. Coastal flood hazard mapping. In Encyclopedia of Coastal Science, 2nd ed.; Springer: Cham, Switzerland, 2018; pp. 471-479. [CrossRef]

14. Batista, C.M.; Suárez, A.; Saltarén, C.M.B. Novel method to delimitate and demarcate coastal zone boundaries. Ocean Coast. Manag. 2017, 144, 105-119. [CrossRef]

15. Pimentel, M.A.D.S.; Szlafsztein, C.F.; Montero, O.P.; Batista, C.M. Sustentabilidade dos meios de vida e vulnerabilidade socioambiental: Estudos compartilhados entre brasil e Cuba. Camin. Geogr. 2021, 22, 249-264. [CrossRef]

16. ONEI. Environmental Overview. Cuba. Havana: Center for Economic, Environmental and Social Information Management. 2019. Available online: http:/ / www.onei.gob.cu (accessed on 1 April 2020).

17. Milanes, C.B.; Montero, O.P.; Cabrera, J.A.; Cuker, B. Recommendations for coastal planning and beach management in Caribbean insular states during and after the COVID-19 pandemic. Ocean Coast. Manag. 2021, 208, 105575. [CrossRef] 
18. Pérez, M.O.; Milanés, B.C.; Poveda, S.I.; Cruz, P.Y. Los estudios de peligro, vulnerabilidad y riesgos de desastres en Cuba. In Experiencias Metodológicas Para la Gestión del Riesgo; Libro de Investigación; Milanés, B.C., Fabian, S.C., Eds.; Editorial Universitaria de la Costa, EDUCOSTA S.A.S.: Barranquilla, Colombia, 2018; pp. 25-63. ISBN 978-958-8921-69-3. Available online: http:/ / repositorio.cuc.edu.co/xmlui/handle/11323/1686 (accessed on 1 June 2019).

19. Citma. Studies of Danger, Vulnerability and Flood Risks by Penetration of the Sea in Santiago de Cuba, Santiago de Cuba. 2017; unpublished results.

20. Pérez, P.R. Rise of the average sea level in Cuba by climate change. Cuba J. Meteorol. 2019, 25, 76-83. Available online: http:/ /rcm.insmet.cu/index.php/rcm/article/view/455/619 (accessed on 10 April 2020).

21. Alonso, G.; Clark, I. Confrontation with climate change in the Republic of Cuba. Int. J. Cuba. Health Med. 2015, 17, 1-19. Available online: https:/ /www.scielosp.org/article/medicc/2015.v17n2/10-13/en/ (accessed on 12 August 2020).

22. Diaz, J.L.; Magas, A.R.; Bouza, O.; Hernández, J. The relief of Cuba. Earth Space Sci. 1990, 33-44. Available online: http: //redciencia.cu/geobiblio/geobiblio.html\#D (accessed on 1 January 2010).

23. Chávez, I.M.B.; Batista, C.M.; Montero, O.P.; Suarez, C.V.; García, M.C. Caracterización de las tipologías del medio físico construido en frentes de playa: Municipio Guamá (Cuba). Módulo Arquit. CUC 2021, 27, 113-144. [CrossRef]

24. Batista, C.M.; Pereira, C.I.; Botero, C.M. Improving a decree law about coastal zone management in a small island developing state: The case of Cuba. Mar. Policy 2019, 101, 93-107. [CrossRef]

25. Nuñez, A.; Planes, V.; Stelcl, O. Speleological and Carsological; Series No. 2; Academy of Sciences of Cuba: Carsos de Cuba, Cuba, 1968.

26. González-Agraz, M.P.; de Maestría, T. Vulnerabilidad de los humedales en la costa tamaulipeca (Publication Number 1), Universidad Autó-noma de Tamaulipas, Tampico, Mexico. 2011; unpublished results.

27. Jiménez-Hernández, S.B.; Salinas-Castillo, W.; Campos-Flores, J. Impacto de la urbanización en zonas costeras, caso de estudio: Zona conurbada Altamira-Madero-Tampico, Tamaulipas, México. In Diag-Nóstico Ambiental del Golfo de México; Caso, M., Pisanty, I., Ezcurra, E., Eds.; Untitled Instituto Nacional de Ecología, 2004; Volume 1, pp. 417-430. Available online: https: / / bit.ly/3fdvtwy (accessed on 25 June 2020).

28. Stucchi, L.; Bignami, D.F.; Bocchiola, D.; Del Curto, D.; Garzulino, A.; Rosso, R. Assessment of climate-driven flood risk and adaptation supporting the conservation management plan of a heritage site. the national art schools of Cuba. Climate 2021, 9, 23. [CrossRef]

29. Batista, M.C. Coastal risk. In Encyclopedia of Coastal Science, 2nd ed.; Finkl, C.W., Makowski, C., Eds.; Springer Nature: Cham, Switzerland, 2018; Volume 1, pp. 524-534. Available online: https://link.springer.com/referenceworkentry/10.1007\%2F978-3-3 19-48657-4_408-1 (accessed on 24 October 2018).

30. Pereira, C.I.; Milanes, C.B.; Sarda, R.; Cuker, B.; Botero, C.M. Challenges at the early stages of the environmental licensing procedure and potential contributions from geomorphology. Geosci. Front. 2021, 12, 101228. [CrossRef]

31. Botero, C.; Pereira, C.; Milanes, C.; Pranzini, E. Dataset of human interventions as anthropogenic perturbations on the Caribbean coast of Colombia. Data Brief 2020, 31, 105847. [CrossRef]

32. Antunes, C.; Rocha, C.; Catita, C. Coastal flood assessment due to sea level rise and extreme storm events: A case study of the atlantic coast of portugal's mainland. Geosciences 2019, 9, 239. [CrossRef]

33. Balica, S.F.; Wright, N.; Van Der Meulen, F. A flood vulnerability index for coastal cities and its use in assessing climate change impacts. Nat. Hazards 2012, 64, 73-105. [CrossRef]

34. Balica, S.F.; Douben, N.; Wright, N.G. Flood vulnerability indices at varying spatial scales. Water Sci. Technol. 2009, 60, 2571-2580. [CrossRef] [PubMed]

35. Boruff, B.J.; Emrich, C.; Cutter, S.L. Erosion hazard vulnerability of US coastal counties. J. Coast. Res. 2005, 215, 932-942. [CrossRef]

36. Giannakidou, C.; Diakoulaki, D.; Memos, C.D. Implementing a flood vulnerability index in urban coastal areas with industrial activity. Nat. Hazards 2019, 97, 99-120. [CrossRef]

37. Gornitz, V. Global coastal hazards from future sea level rise. Palaeogeogr. Palaeoclim. Palaeoecol. 1991, 89, 379-398. [CrossRef]

38. Hughes, P.; Brundrit, G.B. An index to assess south-africa vulnerability to sea-level rise. S. Afr. J. Sci. 1992, 88, 308-311.

39. Mclaughlin, S.; Cooper, J.A.G. A multi-scale coastal vulnerability index: A tool for coastal managers? Environ. Hazards 2010, 9, $233-248$. [CrossRef]

40. Su, S.; Pi, J.; Wan, C.; Li, H.; Xiao, R.; Li, B. Categorizing social vulnerability patterns in Chinese coastal cities. Ocean Coast. Manag. 2015, 116, 1-8. [CrossRef]

41. Zhu, Z.-T.; Cai, F.; Chen, S.-L.; Gu, D.-Q.; Feng, A.-P.; Cao, C.; Qi, H.-S.; Lei, G. Coastal vulnerability to erosion using a multi-criteria index: A case study of the Xiamen coast. Sustainability 2018, 11, 93. [CrossRef]

42. Planas, F.J.A.; Milanés, C.B.; Fanning, L.M.; Botero, C.M. Validating governance performance indicators for integrated coastal and ocean management in the southeast region of Cuba. Open J. Mar. Sci. 2016, 6, 49-65. [CrossRef]

43. Pereira, C.I.; Carvajal, A.F.; Batista, C.M.; Botero, C.M. Regulating human interventions in Colombian coastal areas: Implications for the environmental licensing procedure in middle-income countries. Environ. Impact Assess. Rev. 2019, 79, 106284. [CrossRef]

44. Garcia, E.S.; Loáiciga, H.A. Sea-level rise and flooding in coastal riverine flood plains. Hydrol. Sci. J. 2013, 59, 204-220. [CrossRef]

45. Osland, M.J.; Griffith, K.T.; Larriviere, J.C.; Feher, L.C.; Cahoon, D.R.; Enwright, N.M.; Oster, D.A.; Tirpak, J.M.; Woodrey, M.S.; Collini, R.C.; et al. Assessing coastal wetland vulnerability to sea-level rise along the northern Gulf of Mexico coast: Gaps and opportunities for developing a coordinated regional sampling network. PLoS ONE 2017, 12, e0183431. [CrossRef] [PubMed] 
46. Wang, H.; Chen, Q.; Hu, K.; La Peyre, M.K. A modeling study of the impacts of mississippi river diversion and sea-level rise on water quality of a deltaic estuary. Chesap. Sci. 2016, 40, 1028-1054. [CrossRef]

47. Batista, C.M. Coastal boundaries. In Encyclopedia of Remote Sensing, 2nd ed.; Encyclopedia of Coastal Science; Finkl, C.W., Makowski, C., Eds.; Springer Nature: Cham, Switzerland, 2018; Volume 1, pp. 414-426. [CrossRef]

48. Adams, H.; Kay, S. Migration as a human affair: Integrating individual stress thresholds into quantitative models of climate migration. Environ. Sci. Policy 2019, 93, 129-138. [CrossRef]

49. Kantamaneni, K.; Gallagher, A.; Du, X. Assessing and mapping regional coastal vulnerability for port environments and coastal cities. J. Coast. Conserv. 2019, 23, 59-70. [CrossRef]

50. Reece, J.S.; Watson, A.; Dalyander, P.S.; Edwards, C.K.; Geselbracht, L.; Lapeyre, M.K.; Tirpak, B.E.; Tirpak, J.M.; Woodrey, M. A multiscale natural community and species-level vulnerability assessment of the Gulf coast, USA. PLoS ONE 2018, 13, e0199844. [CrossRef] [PubMed]

51. Milanés, C.; Batista, Á.R.; Núñez, R.A.; Yero, H.T. Development of a mobile application for early warning systems and risk management in Cuba. IOP Conf. Ser. Mater. Sci. Eng. 2021, 1154, 012005. Available online: https://iopscience.iop.org/article/10. 1088/1757-899X/1154/1/012005 (accessed on 25 March 2021). [CrossRef]

52. Milanés, B.C.; Pérez, M.O. Ordenamiento Y Manejo Integrado de la Zona Costera Frente a Los Riesgos del Cambio Climático en la Región Suroriental de Cuba; Revista Anales de la Academia de ciencias de Cuba, 2016; Volume 6, ISSN 2304-0106. Available online: http:/ / www.revistaccuba.cu/index.php/revacc/article/view/572 (accessed on 25 June 2020).

53. Batista, C.M.; Planas, J.A.; Pelot, R.; Núñez, J.R. A new methodology incorporating public participation within Cuba's ICZM program. Ocean Coast. Manag. 2020, 186, 105101. [CrossRef]

54. Ojeda, E.; Appendini, C.M.; Mendoza, E.T. Storm-wave trends in Mexican waters of the Gulf of Mexico and Caribbean Sea. Nat. Hazards Earth Syst. Sci. 2017, 17, 1305-1317. [CrossRef]

55. Martínez, M.L.; Mendoza-González, G.; Silva-Casarín, R.; Mendoza-Baldwin, E. Land use changes and sea level rise may induce a "coastal squeeze" on the coasts of Veracruz, Mexico. Glob. Environ. Chang. 2014, 29, 180-188. [CrossRef]

56. Bilskie, M.V.; Hagen, S.C.; Medeiros, S.C.; Cox, A.T.; Salisbury, M.; Coggin, D. Data and numerical analysis of astronomic tides, wind-waves, and hurricane storm surge along the northern Gulf of Mexico. J. Geophys. Res. Oceans 2016, 121, 3625-3658. [CrossRef]

57. De Edición Agosto, C.; GEOCUBA. Derrotero de las Costas de Cuba; Generalidades. (C) EDIMAR.; Agencia de Cartografía Náutica, 2003; Available online: http:/ / www.iderc.cu/documents/10523/107380/P+1103/352e0251-ad7b-4523-b5d0-b8a615729333 (accessed on 12 July 2010).

58. Montero, O.P.; Soler, P.A.B.; Fajardo, J.A.P.; Santana, I.P.; Hierrezuelo, M.M. Gender approach in the integrated coastal zone management program at Sevilla, Cuba. Ocean Yearb. Online 2015, 29, 192-221. [CrossRef]

59. Pérez, M.O.; Carbonero, M.A.; Poveda, I.; Gómez, M.; Oliver, M.A. Cuando la mujer migra. Una mirada a las migraciones internas, desde la perspectiva del desarrollo sostenible, en el municipio costero de Guama, Santiago de Cuba. Rev. Noved. Poblac. 2018, 14, 23-25. Available online: http:/ / www.novpob.uh.cu (accessed on 25 June 2020).

60. Montero, O.P.; Batista, C.M. Social perception of coastal risk in the face of hurricanes in the southeastern region of Cuba. Ocean Coast. Manag. 2020, 184, 105010. [CrossRef]

61. Portorreal, Y.C.; Montero, O.P. Evaluación de impactos a la salud del manglar en el municipio Guamá, Santiago de Cuba, Cuba. Madera Y Bosques 2017, 23, 27-41. [CrossRef]

62. IPF. Instituto de Planificación Física. In Plan General de Ordenamiento Territorial Urbano (PGOTU); Municipio Guama de la Provincia de Santiago de Cuba, Instituto de Planificación Física: Santiago de Cuba, Cuba, 2015.

63. Ferrera, W.V.; Pérez, M.O.; Soler, N.O. Población y vulnerabilidad social ante los efectos del cambio climático en el munici-pio costero de Guama. Rev. Noved. Poblac. 2020, 16, 242-269. Available online: http:/ /www.novpob.uh.cu. (accessed on 25 September 2020).

64. Iturralde, V.M. Typology, training, and transformation of the coasts of Cuba. In Integrated Management of Coastal Zones in Cuba: Current State, Challenges and Challenges; Contemporary Image Editions: Havana, Cuba, 2015; pp. 129-151.

65. Chen, J.Y. The impact of sea level rise on China's coastal areas and its disaster hazard evaluation. J. Coast. Res. 1997, 13, 925-930. Available online: http:/ / www.jstor.org/stable/4298685 (accessed on 25 June 2020).

66. Garcia, J.P.G.M. Origins, management, and measurement of stress on the coast of southern Spain. Coast. Manag. 2000, 28, 215-234. [CrossRef]

67. Freitas, M.; Andrade, C.; Cachado, C.; Cardoso, A.; Monteiro, J.; Brito, P.; Rebelo, L. Coastal land-loss associated with sea-level rise assessed by aerial videotape-assisted vulnerability analysis-The case of mainland Portugal. J. Coast. Res. 2006, 1310-1315. Available online: http:/ / www.jstor.org/stable/25742966 (accessed on 25 June 2020).

68. Morabito, M.; Crisci, A.; Gioli, B.; Gualtieri, G.; Toscano, P.; Di Stefano, V.; Orlandini, S.; Gensini, G.F. Urban-hazard risk analysis: Mapping of heat-related risks in the elderly in major Italian cities. PLoS ONE 2015, 10, e0127277. [CrossRef] [PubMed]

69. Koroglu, A.; Ranasinghe, R.; Jimenez, J.A.; Dastgheib, A. Comparison of coastal vulnerability index applications for barcelona province. Ocean Coast. Manag. 2019, 178, 104799. [CrossRef]

70. Ferreira, Ó.; Plomaritis, T.A.; Costas, S. Effectiveness assessment of risk reduction measures at coastal areas using a decision support system: Findings from Emma storm. Sci. Total. Environ. 2019, 657, 124-135. [CrossRef]

71. Rey-Valette, H.; Robert, S.; Rulleau, B. Resistance to relocation in flood-vulnerable coastal areas: A proposed composite index. Clim. Policy 2019, 19, 206-218. [CrossRef] 
72. Dou, X.; Song, J.; Wang, L.; Tang, B.; Xu, S.; Kong, F.; Jiang, X. Flood risk assessment and mapping based on a modified multiparameter flood hazard index model in the Guanzhong urban area, China. Stoch. Environ. Res. Risk Assess. 2017, 32, 1131-1146. [CrossRef]

73. Klein, R.J.; Nicholls, R.J. Assessment of coastal vulnerability to climate change. Ambio 1999, 28, $182-187$.

74. Sekovski, I.; Del Río, L.; Armaroli, C. Development of a coastal vulnerability index using analytical hierarchy process and application to Ravenna province (Italy). Ocean Coast. Manag. 2020, 183, 104982. [CrossRef]

75. Mullick, M.R.A.; Tanim, A.; Islam, S.M.S. Coastal vulnerability analysis of Bangladesh coast using fuzzy logic based geospa-tial techniques. Ocean Coast. Manag. 2019, 174, 154-169. [CrossRef]

76. Özyurt, G.; Ergin, A. Application of sea level rise vulnerability assessment model to selected coastal areas of Turkey. J. Coast. Res. 2009, 56, 248-251. Available online: http:/ / www.jstor.org/stable/25737575 (accessed on 18 July 2020).

77. Özyurt, G.; Ergin, A. Improving coastal vulnerability assessments to sea-level rise: A new indicator-based methodology for decision makers. J. Coast. Res. 2010, 262, 265-273. [CrossRef]

78. Ojeda, Z.J.; Álvarez, F.J.; Martín, C.D.; Fraile, J.P. El uso de las tecnologías de la información geográfica para el cálculo del índice de vulnerabilidad costera (CVI) ante una potencial subida del nivel del mar en la costa andaluza (España). GeoFocus 2009, 9 , 83-100. Available online: http://www.geofocus.org/index.php/geofocus/article/view/162 (accessed on 25 December 2020).

79. Anfuso, G.; Martínez, P.J.Á. Assessment of coastal vulnerability through the use of GIS tools in south Sicily (Italy). Environ. Manag. 2009, 43, 533-545. [CrossRef]

80. Gornitz, V. Vulnerability of the east coast, USA to future sea level rise. J. Coast. Res. 1990, 9, 201-237.

81. Dal Cin, R.; Simeoni, U. A model for determining the classification, vulnerability, and risk in the southern coastal zone of the Marche (Italy). J. Coast. Res. 1994, 10, 18-29.

82. Narra, P.; Coelho, C.; Sancho, F. Multicriteria GIS-based estimation of coastal erosion risk: Implementation to Aveiro sandy coast, Portugal. Ocean Coast. Manag. 2019, 178, 104845. [CrossRef]

83. Handayani, W.; Rudiarto, I.; Setyono, J.S.; Chigbu, U.E.; Sukmawati, A.M. Vulnerability assessment: A comparison of three different city sizes in the coastal area of central java, indonesia. Adv. Clim. Chang. Res. 2017, 8, 286-296. [CrossRef]

84. Wang, X.; Xu, L.-L.; Cui, S.-H.; Wang, C.-H. Reflections on coastal inundation, climate change impact, and adaptation in built environment: Progresses and constraints. Adv. Clim. Chang. Res. 2020, 11, 317-331. [CrossRef]

85. Pendleton, E.A.; Thieler, E.R.; Williams, S.J. Relative Coastal Change-Potential Assessment of Glacier Bay National Park and Preserve: U.S. Geological Survey Open-File Report 20051247. 2006. Available online: Pubs.usgs.gov/of/2005/1247 (accessed on 25 June 2020).

86. Pendleton, E.A.; Thieler, E.R.; Williams, S.J. Importance of coastal change variables in determining vulnerability to sea- and lake-level change. J. Coast. Res. 2010, 261, 176-183. [CrossRef]

87. Rangel-Buitrago, N.; Neal, W.J.; de Jonge, V.N. Risk assessment as tool for coastal erosion management. Ocean Coast. Manag. 2020, 186, 105099. [CrossRef]

88. Díaz-Cuevas, P.; Prieto-Campos, A.; Ojeda-Zújar, J. Developing a beach erosion sensitivity indicator using relational spatial databases and analytic hierarchy process. Ocean Coast. Manag. 2020, 189, 105146. [CrossRef]

89. Rizzo, A.; Aucelli, P.P.C.; Gracia, F.J.; Anfuso, G. A novelty coastal susceptibility assessment method: Application to valdelagrana area (SW Spain). J. Coast. Conserv. 2017, 22, 973-987. [CrossRef]

90. Bautista, P.A.; Bautista, H.F.D.A. The Clic-MD software a tool to analyze thousands of data in seconds: Trends of climate and agro climatic indices. Ecosistemas Y Recur. Agropecu. 2021, 8, e2637. [CrossRef]

91. Bertilsson, L.; Wiklund, K.; Tebaldi, I.D.M.; Rezende, O.M.; Veról, A.P.; Miguez, M.G. Urban flood resilience-A multi-criteria index to integrate flood resilience into urban planning. J. Hydrol. 2019, 573, 970-982. [CrossRef]

92. Velázquez, L.Y.; Pérez, B.M.; Castellanos, G.J. La gestión ambiental post COVID-19 y su contribución a la integridad ecológica de las playas en Cuba. In El Turismo de Sol y Playa en el Con-Texto de la COVID-19; Botero, C.M., Mercadé, S., Cabrera, J.A., Bombana, B., Eds.; Publicación en el marco de la Red Iberoamericana de Ges-tión y Certificación de Playas-PROPLAYAS: Santa Marta, Colombia, 2020; pp. 49-52. ISBN 978-958-53064-0-0. Available online: http://www.proplayas.org/covid19/ (accessed on 18 May 2020).

93. Calil, J.; Reguero, B.G.; Zamora, A.R.; Losada, I.J.; Mendez, F.J. Comparative Coastal Risk Index (CCRI): A multidisciplinary risk index for Latin America and the Caribbean. PLoS ONE 2017, 12, e0187011. [CrossRef]

94. Pricope, N.G.; Halls, J.N.; Rosul, L.M. Modeling residential coastal flood vulnerability using finished-floor elevations and socio-economic characteristics. J. Environ. Manag. 2019, 237, 387-398. [CrossRef]

95. Jaranovic, B.; Trindade, J.; Ribeiro, J.; Silva, A. Using a coastal storm hazard index to assess storm impacts in lisbon. Int. J. Saf. Secur. Eng. 2017, 7, 221-233. [CrossRef]

96. Milanes, C.; Martínez-González, M.; Moreno-Gómez, J.; Saltarín-Jiménez, A.; Suarez, A.; Padilla-Llano, S.; Vasquez, A.; Lavell, A.; Zielinski, S. Multiple hazards and governance model in the Barranquilla metropolitan area, Colombia. Sustainability 2021, 13, 2669. [CrossRef]

97. Milanés, C.; Acosta, B. Metodología Para el Ordenamiento Marino Costero en Playas; Corporación Universi-dad de la Costa: Barranquilla, Colombia, 2021; Available online: https:/ / repositorio.cuc.edu.co/handle/11323/8384. (accessed on 25 June 2021).

98. Armaroli, C.; Duo, E. Validation of the coastal storm risk assessment framework along the Emilia-Romagna coast. Coast. Eng. 2018, 134, 159-167. [CrossRef] 
99. Khan, A.; Soumendu, C. Coastal Risk Assessment: A Comprehensive Framework for the Bay of Bengal; Springer Briefs in Oceanography: Berlin/Heidelberg, Germany, 2018; p. 86. ISBN 331969992X, 9783319699929.

100. Okada, T.; Mito, Y.; Iseri, E.; Takahashi, T.; Sugano, T.; Akiyama, Y.B.; Watanabe, K.; Tanaya, T.; Sugino, H.; Tokunaga, K.; et al. Method for the quantitative evaluation of ecosystem services in coastal regions. PeerJ 2019, 6, e6234. [CrossRef] [PubMed]

101. Ružić, I.; Jovančević, S.D.; Benac, Č.; Krvavica, N. Assessment of the coastal vulnerability index in an area of complex geological conditions on the Krk island, northeast Adriatic Sea. Geosciences 2019, 9, 219. [CrossRef]

102. Zhang, D.; Shi, X.; Xu, H.; Jing, Q.; Pan, X.; Liu, T.; Wang, H.; Hou, H. A GIS-based spatial multi-index model for flood risk assessment in the Yangtze River Basin, China. Environ. Impact Assess. Rev. 2020, 83, 106397. [CrossRef]

103. Tortell, P. Coastal zone sensitivity mapping and its role in marine environmental management. Mar. Pollut. Bull. 1992, 25, 88-93. [CrossRef]

104. Armenio, E.; Mossa, M.; Petrillo, A.F. Coastal vulnerability analysis to support strategies for tackling COVID-19 infection. Ocean Coast. Manag. 2021, 211, 105731. [CrossRef]

105. Cai, J.; Huang, B.; Song, Y. Using multi-source geospatial big data to identify the structure of polycentric cities. Remote. Sens. Environ. 2017, 202, 210-221. [CrossRef]

106. Kim, A.M. Critical cartography 2.0: From "participatory mapping" to authored visualizations of power and people. Landsc. Urban Plan. 2015, 142, 215-225. [CrossRef]

107. Anfuso, G.; Postacchini, M.; Di Luccio, D.; Benassai, G. Coastal sensitivity/vulnerability characterization and adaptation strategies: A review. J. Mar. Sci. Eng. 2021, 9, 72. [CrossRef]

108. Bartlett, D.; Smith, J. GIS for coastal zone management. In GIS for Coastal Zone Management, 1st ed.; Bartlett, D., Smith, J., Eds.; CRC Press: Boca Raton, FL, USA, 2004. [CrossRef]

109. Seenath, A.; Wilson, M.; Miller, K. Hydrodynamic versus GIS modelling for coastal flood vulnerability assessment: Which is better for guiding coastal management? Ocean Coast. Manag. 2016, 120, 99-109. [CrossRef] 